\title{
Synthesis of nickel/gallium nanoalloys using a dual-source approach in 1-alkyl-3-methylimidazole ionic liquids
}

\author{
Ilka Simon ${ }^{1}$, Julius Hornung ${ }^{2}$, Juri Barthel ${ }^{3}$, Jörg Thomas ${ }^{4}$, Maik Finze ${ }^{5}$, \\ Roland A. Fischer ${ }^{2}$ and Christoph Janiak ${ }^{*} 1, \S$
}

\section{Full Research Paper}

\section{Address:}

${ }^{1}$ Institut für Anorganische Chemie und Strukturchemie, Heinrich-Heine-Universität Düsseldorf, 40204 Düsseldorf, Germany, 2Lehrstuhl für Anorganische und Metallorganische Chemie TU München, Lichtenbergstr. 4, 85748 Garching, Germany, ${ }^{3}$ Gemeinschaftslabor für Elektronenmikroskopie RWTH-Aachen, Ernst Ruska-Centrum für Mikroskopie und Spektroskopie mit Elektronen, 52425 Jülich, Germany, ${ }^{4}$ Department Structure and Nano-/Micromechanics of Materials, Max-Planck-Institut für Eisenforschung $\mathrm{GmbH}, 40237$ Düsseldorf, Germany and ${ }^{5}$ Institut für Anorganische Chemie, Institut für nachhaltige Chemie \& Katalyse mit Bor (ICB), Julius-Maximilians-Universität Würzburg, Am Hubland, 97074 Würzburg, Germany

Email:

Christoph Janiak* - janiak@uni-duesseldorf.de

* Corresponding author

§ Fax: +49-211-81-12287; Tel: +49-211-81-12286

Keywords:

ionic liquids; microwave decomposition; nickel/gallium nanoparticles; semihydrogenation catalysis; soft wet-chemical synthesis
Beilstein J. Nanotechnol. 2019, 10, 1754-1767. doi:10.3762/bjnano.10.171

Received: 26 April 2019

Accepted: 24 July 2019

Published: 21 August 2019

Associate Editor: J. J. Schneider

(C) 2019 Simon et al.; licensee Beilstein-Institut. License and terms: see end of document.

\footnotetext{
Abstract

$\mathrm{NiGa}$ is a catalyst for the semihydrogenation of alkynes. Here we show the influence of different dispersion times before microwave-induced decomposition of the precursors on the phase purity, as well as the influence of the time of microwave-induced decomposition on the crystallinity of the NiGa nanoparticles. Microwave-induced co-decomposition of all-hydrocarbon precursors $\left[\mathrm{Ni}(\mathrm{COD})_{2}\right](\mathrm{COD}=1,5$-cyclooctadiene $)$ and $\mathrm{GaCp}^{*}\left(\mathrm{Cp}^{*}=\right.$ pentamethylcyclopentadienyl $)$ in the ionic liquid [BMIm] $\left[\mathrm{NTf}_{2}\right]$ selectively yields small intermetallic $\mathrm{Ni} / \mathrm{Ga}$ nanocrystals of $5 \pm 1 \mathrm{~nm}$ as derived from transmission electron microscopy (TEM) and high-angle annular dark-field scanning transmission electron microscopy (HAADF-STEM) and supported by energy-dispersive X-ray spectrometry (EDX), selected-area energy diffraction (SAED) and X-ray photoelectron spectroscopy (XPS). $\mathrm{NiGa@[BMIm]}\left[\mathrm{NTf}_{2}\right]$ catalyze the semihydrogenation of 4-octyne to 4-octene with $100 \%$ selectivity towards $(E)$-4-octene over five runs, but with poor conversion values. IL-free, precipitated $\mathrm{NiGa}$ nanoparticles achieve conversion values of over $90 \%$ and selectivity of $100 \%$ towards alkene over three runs.
} 


\section{Introduction}

The synthesis of Ni nanoparticles is well known and is most commonly carried out in organic solvents using reducing agents [1], thermal decomposition [2] or reductive hydrogenation [3]. Applications for Ni nanoparticles are Wittig-type olefination [4], Suzuki cross-coupling [5] and catalytic hydrogenation reactions [6]. The catalytic activity of Ni nanoparticles can be used in hydrogenation reactions of alkenes [7], styrene [8], and quinoline [9]. Semihydrogenation reactions of alkynes lead to overhydrogenation [10] or polymerization in the case of acetylene to form oligomers [11]. One can distinguish between the more stable face-centered cubic (fcc) [12] and the less stable hexagonal close-packed (hcp) [13] Ni phase. The magnetic properties of fcc Ni nanoparticles are similar to the bulk material with saturation magnetization values of $50 \mathrm{emu} / \mathrm{g}_{\mathrm{Ni}}$ at $300 \mathrm{~K}$ [14]. Hcp Ni nanoparticles show very weak magnetic features with saturation magnetization values below $1 \mathrm{emu} / \mathrm{g}_{\mathrm{Ni}}$ at $300 \mathrm{~K}$ [15]. Ni nanoparticles can easily be prepared from bis $(1,5-$ cyclooctadiene)nickel $(0)\left(\mathrm{Ni}(\mathrm{COD})_{2}\right)$ in organic solvents [16] with the $\mathrm{Ni}$ atom already in the oxidation state zero and a low decomposition temperature of $60^{\circ} \mathrm{C}$ [17]. Alternatively, ionic liquids can be used as solvents and stabilization agents for different metal nanoparticles from metal carbonyls [18] or organometallic complexes [19]. Ni nanoparticles from $\mathrm{Ni}(\mathrm{COD})_{2}$ in ionic liquids can be obtained through spontaneous decomposition [20] or decomposition induced by microwave heating [21] as well as through ligand hydrogenation [22].

The complete removal of alkynes from alkenes is very important in industrial olefin polymerization reactions. Examples are the separation of acetylene from ethylene [22,23] or of phenylacetylene from styrene [24]. The presence of small quantities of alkynes significantly reduces the efficiency of catalysts in the subsequent polymerization reactions. Semihydrogenation reactions are an interesting way not only to remove but also to convert the alkynes to the respective polymerizable alkenes [25]. The addition of main-group metals such as gallium to transition metals can significantly improve the catalytic selectivity towards semihydrogenation reactions, e.g., PdGa [26-28] and RhGa [29]. Intermetallic nanoparticles of nickel and gallium have been proven as efficient catalysts in semihydrogenation reactions experimentally $[30,31]$ and reasoned by theory [32]

The phase diagram of Ni/Ga shows nine different $\mathrm{Ni} / \mathrm{Ga}$ phases (Supporting Information File 1, Figure S1) [33-36]. In a comparison of the $\mathrm{CO}_{2}$ hydrogenation abilities of $\mathrm{NiGa}(\beta), \mathrm{Ni}_{3} \mathrm{Ga}$ $(\alpha)$ and $\mathrm{Ni}_{5} \mathrm{Ga}_{3}(\delta)$ high selectivities towards the formation of methanol were found for $\mathrm{Ni}_{5} \mathrm{Ga}_{3}$ and $\mathrm{NiGa}$ [37]. At $165{ }^{\circ} \mathrm{C}$ $\mathrm{Ni}_{5} \mathrm{Ga}_{3}(\delta)$ yielded $100 \%$ selectivity towards methanol [38]. Above $220{ }^{\circ} \mathrm{C} \mathrm{Ni}_{5} \mathrm{Ga}_{3}$ is even more active than a conventional $\mathrm{Cu} / \mathrm{ZnO} / \mathrm{Al}_{2} \mathrm{O}_{3}$ catalyst with less $\mathrm{CO}$ formation in the reverse water-gas shift reaction (rWGS). In $\mathrm{Ni}_{5} \mathrm{Ga}_{3}$ the Ga-rich step sites facilitate the methanol synthesis, the Ni-rich sites get selfpoisoned by methanation and $\mathrm{CO}$ formation through rWGS [37]. In conclusion, $\mathrm{Ni}_{5} \mathrm{Ga}_{3}(\delta)$ was found to be the most active catalyst for $\mathrm{CO}_{2}$ hydrogenation [39-41]. Semihydrogenation of phenylacetylene to styrene using $\mathrm{NiGa}, \mathrm{Ni}_{3} \mathrm{Ga}$ and $\mathrm{Ni}_{5} \mathrm{Ga}_{3}$ as catalysts indicated that using $\mathrm{Ni}_{3} \mathrm{Ga}(\alpha)$ yielded the highest activity with a turnover frequency (TOF) of $5.16 \times 10^{-3} \mathrm{~h}^{-1}$ with the highest selectivities $[10,30,32,42]$.

Bimetallic nanoparticles containing Ga are difficult to synthesize from $\mathrm{Ga}^{3+}$ precursors, because of the high negative redox potential of $\mathrm{Ga}^{3+}$ as well as the low melting point of Ga metal leading to coagulation. During the synthesis of NiGa [42] or PdGa [27] nanoparticles from $\mathrm{Ni}^{2+}$ or $\mathrm{Pd}^{2+}$ precursors, using aminoborane as reducing agent, the formation of a transitionmetal hydride was reported as a first step. These hydrides can then reduce the $\mathrm{Ga}^{3+}$ precursor, working as a nucleation center for the Ga atoms and prevent uncontrolled coagulation of the liquid metal. Through annealing, the single-phase products can be obtained [27,42].

The all-hydrocarbon precursor $\mathrm{GaCp}^{*}\left(\mathrm{Cp}^{*}=\right.$ pentamethylcyclopentadienyl), with the $\mathrm{Ga}$ atom in the oxidation state +1 , was reported to form phase-pure $\mathrm{NiGa}$ and $\mathrm{Ni}_{3} \mathrm{Ga}$ nanoparticles with $\mathrm{Ni}(\mathrm{COD})_{2}$ in the ionic liquid $[\mathrm{BMIm}]\left[\mathrm{BF}_{4}\right]$ under microwaveinduced pyrolysis at $230{ }^{\circ} \mathrm{C}$ [30]. GaCp* is reported to be thermally stable in organic solvents in the absence of hydrogen to up to $300{ }^{\circ} \mathrm{C}$ [43]. In imidazolium-based ionic liquids decomposition of $\mathrm{GaCp}^{*}$ is possible at temperatures below $300{ }^{\circ} \mathrm{C}$ with the aid of transition metals. Reactions of transition-metal complexes are reported to show H/D activation/exchange reactions at the $\mathrm{C} 2$ imidazolium carbon atom of the ionic liquid cation. The generated N-heterocyclic carbene ligands (NHC) stabilize metal clusters and nanoparticles [44]. By insertion of the transition-metal center into the $\mathrm{C} 2-\mathrm{H}$ bond of imidazolium salts, transition-metal hydride complexes are formed [45]. Finally, $\mathrm{H}$ transfer reactions from the transition metal to $\mathrm{GaCp}^{*}$ lead to the release of $\mathrm{Cp}^{*} \mathrm{H}$ without additional hydrogen [46]. Here, small $\mathrm{NiGa}$ nanoparticles were synthesized from $\mathrm{Ni}(\mathrm{COD})_{2}$ and $\mathrm{GaCp}^{*}$ in the ionic liquid [BMIm] $\left[\mathrm{NTf}_{2}\right]$. The nanoparticles were characterized and tested for the semihydrogenation reaction of 4-octyne following our work on the selective semihydrogenation reaction of the terminal alkyne 1-octyne and the internal alkyne diphenylacetylene with yields of $90 \%$ and selectivities of $94 \%$ and $87 \%$, respectively [30].

\section{Results and Discussion}

$\mathrm{Ni}(\mathrm{COD})_{2}$ and $\mathrm{GaCp}^{*}$ were dispersed in equimolar ratio in [BMIm] $\left[\mathrm{NTf}_{2}\right]$ for $24 \mathrm{~h}$ prior to the thermal decomposition. 
Through microwave irradiation at $230{ }^{\circ} \mathrm{C}$, a black powder was obtained after $10 \mathrm{~min}$. The TEM measurements show spherical and non-aggregated nanoparticles with a narrow size distribution of $3.0 \pm 0.5 \mathrm{~nm}$ (Figure 1). To validate the intermetallic 1:1 $\mathrm{NiGa}$ phase of the obtained nanoparticles, powder X-ray diffraction pattern (P-XRD) or selected-area energy diffraction (SAED) are required. Presumably, due to the small size of the nanoparticles, these measurements yielded no diffractograms. Therefore, the nanoparticles can only be described as non-crystalline or amorphous. Quantification of EDX spectra from three different spots on the TEM grid gave a nearly equimolar ratio of nickel to gallium of $46: 54$ atom $\%( \pm 1$ atom $\%)$. No oxygen peak was detected.

The ionic liquid $[\mathrm{BMIm}]\left[\mathrm{BF}_{4}\right]$ and the organic propylene carbonate (PC) yield, under the same reaction conditions, small non-aggregated and non-crystalline $\mathrm{Ni} / \mathrm{Ga}$ nanoparticles (Figure 2) of a size distribution of $2.5 \pm 0.5 \mathrm{~nm}$ ([BMIm] $\left[\mathrm{BF}_{4}\right]$, Supporting Information File 1, Figure S2 and Figure S3) and $5 \pm 1 \mathrm{~nm}$ (PC, Supporting Information File 1, Figure S4). EDX quantification over different spots on the TEM grid also shows equimolar ratios of nickel to gallium (Supporting Information File 1, Figure S2 and Figure S3).

Annealing of nanoparticle samples is known to improve the crystallinity of the nanoparticles $[47,48]$. The decomposition of $\mathrm{Ni}(\mathrm{COD})_{2}$ and $\mathrm{GaCp}^{*}$ in $[\mathrm{BMIm}]\left[\mathrm{NTf}_{2}\right]$ was repeated under the same conditions, but with a longer decomposition time of $30 \mathrm{~min}$, in order to induce annealing in the microwave reactor. Subsequently, the TEM images show spherical and crystalline nanoparticles with a small size distribution of $5 \pm 1 \mathrm{~nm}$ (Figure 3). Through the increased decomposition time the particles were grown slightly larger. The metal composition quantification by EDX spectra from three different spots on the TEM grid gave an equimolar ratio of nickel to gallium of $47: 53$ atom $\%( \pm 1$ atom $\%)$. The formation of intermetallic NiGa $(\beta)$ nanoparticles was verified by SAED measurements (Figure 3, NiGa space group $P m \overline{3} m$ ).

To elucidate the influence of the dispersion time prior to the microwave-induced thermal decomposition of $\mathrm{Ni}(\mathrm{COD})_{2}$ and $\mathrm{GaCp}^{*}$, two samples with shorter dispersion times of $1 \mathrm{~h}$ and
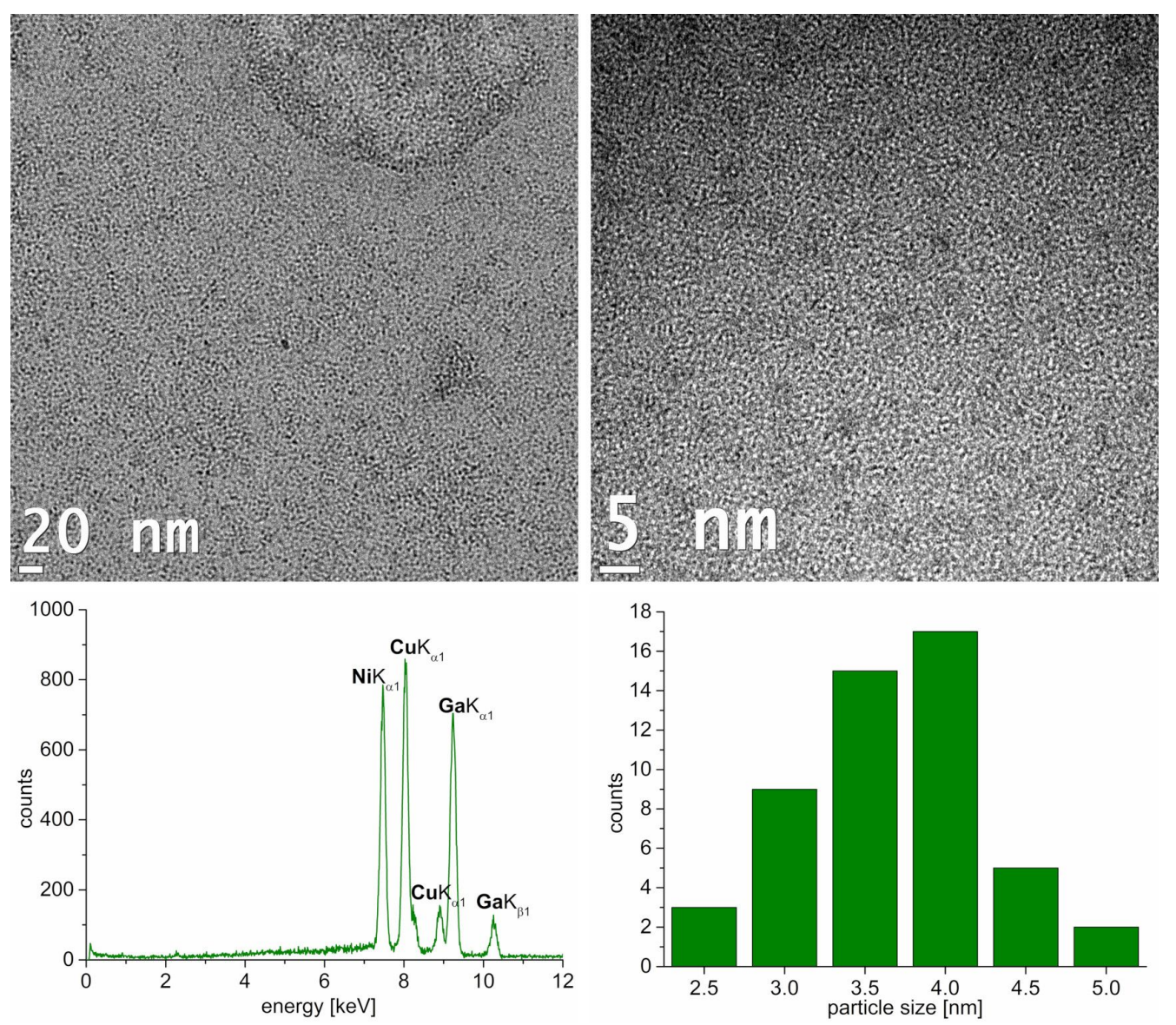

Figure 1: Top: HRTEM images of Ni/Ga nanoparticles from a $0.5 \mathrm{wt} \%$ dispersion of $\mathrm{Ni}(\mathrm{COD})_{2}$ and $\mathrm{GaCp}^{*}$ in $[\mathrm{BMIm}]\left[\mathrm{NTf} \mathrm{f}_{2}\right]$ after $24 \mathrm{~h}$ of dispersion and $10 \mathrm{~min}$ of microwave-induced decomposition. Bottom: EDX spectrum and particle size distribution $3 \pm 0.5 \mathrm{~nm}$ ( $87 \mathrm{particles}$ counted). 

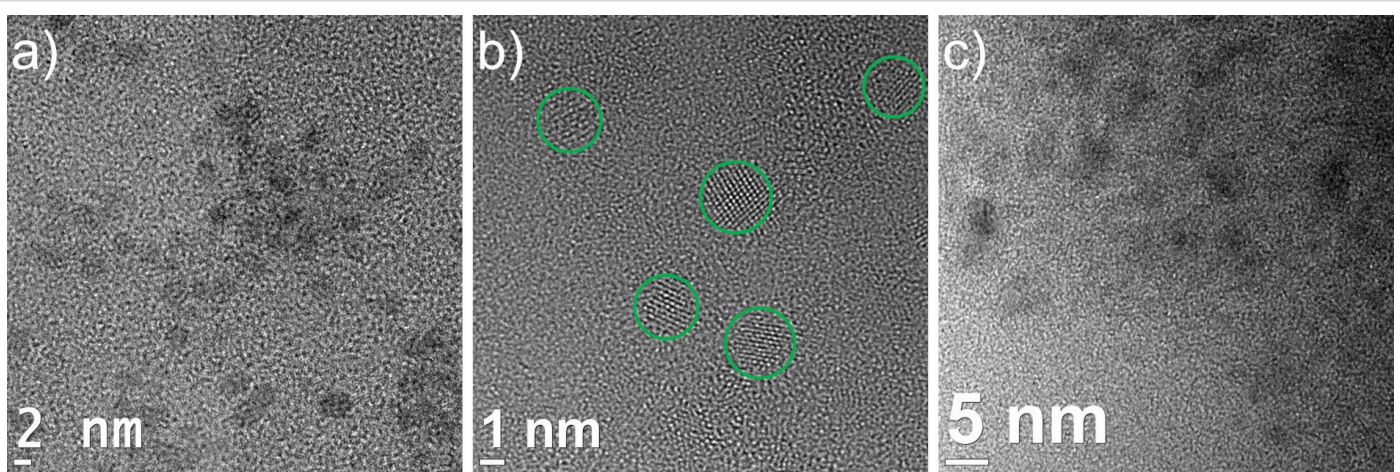

Figure 2: HRTEM images: a) Ni/Ga nanoparticles from a $1 \mathrm{wt} \%$ dispersion of $\mathrm{Ni}(\mathrm{COD})_{2}$ and $\mathrm{GaCp}^{*}$ in $\left[\mathrm{BMIm}\left[\mathrm{BF}_{4}\right]\right.$ after $24 \mathrm{~h}$ of dispersion and $10 \mathrm{~min}$ of microwave-induced decomposition. For details of the particle size distribution $(2.5 \pm 0.5 \mathrm{~nm})$, see Supporting Information File 1, Figure S2.

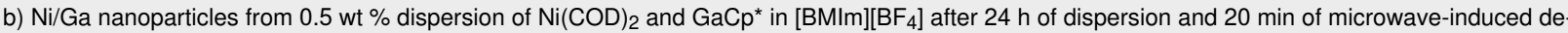
composition. For details of the particle size distribution $(2.5 \pm 0.5 \mathrm{~nm})$, see Supporting Information File 1, Figure S3. c) Ni/Ga nanoparticles from $0.5 \mathrm{wt} \%$ dispersion of $\mathrm{Ni}(\mathrm{COD})_{2}$ and $\mathrm{GaCp}^{*}$ in propylene carbonate after $24 \mathrm{~h}$ of dispersion and $20 \mathrm{~min}$ of microwave-induced decomposition. For details of the particle size distribution $(5 \pm 1 \mathrm{~nm})$, see Supporting Information File 1, Figure S4.
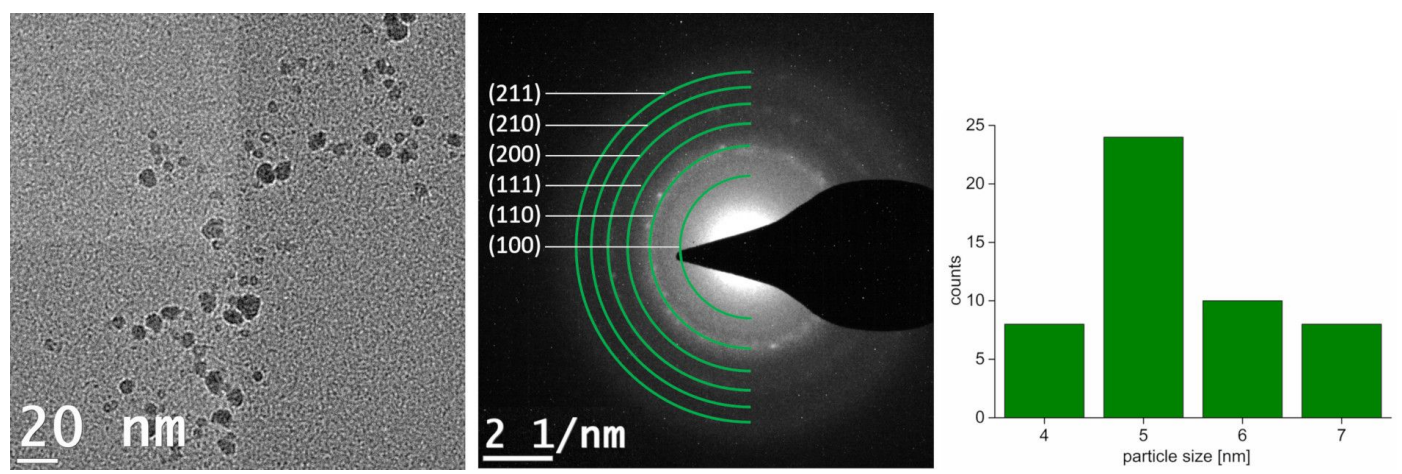

Figure 3: HRTEM image and particle size distribution of $0.5 \mathrm{wt} \%$ dispersion of NiGa nanoparticles from Ni(COD $)_{2}$ and $\mathrm{GaCp}^{*}$ in $[\mathrm{BMIm}]\left[\mathrm{NTf} f_{2}\right]$ after $24 \mathrm{~h}$ of dispersion and $30 \mathrm{~min}$ of microwave-induced decomposition. SAED with indexed reflections for NiGa (space group Pm3 $\mathrm{m}$ ). Particle size distribution $5 \pm 1 \mathrm{~nm}$ ( 50 particles counted).

$12 \mathrm{~h}$ were prepared. $\mathrm{Ni}(\mathrm{COD})_{2}$ and $\mathrm{GaCp}^{*}$ were dispersed in equimolar ratio in $[\mathrm{BMIm}]\left[\mathrm{NTf}_{2}\right]$ for $1 \mathrm{~h}$ prior to the thermal decomposition. Through microwave irradiation at $230{ }^{\circ} \mathrm{C}$, a black powder was obtained after $30 \mathrm{~min}$. The TEM measurements show two different sizes of spherical, crystalline and aggregated nanoparticles (Figure 4). The SAED patterns can be differentiated into the cubic NiGa phase and orthorhombic $\mathrm{Ga}(\mathrm{Ni})$ phase (Figure 4, space group: NiGa $P m \overline{3} m, \mathrm{Ga}(\mathrm{Ni}$ ): Cmce. For the SAED pattern of only the small particles see Supporting Information File 1, Figure S5, bottom). The presence of the Ga-rich phases $\mathrm{Ni}_{3} \mathrm{Ga}_{4}, \mathrm{Ni}_{2} \mathrm{Ga}_{3}, \mathrm{Ni}_{3} \mathrm{Ga}_{7}$ and $\mathrm{NiGa}_{5}$, which exist in the $\mathrm{Ni} / \mathrm{Ga}$ phase diagram can be excluded by SAED measurements (for comparison see Supporting Information File 1, Table S1).

Quantification of the EDX spectrum of mostly the large particles show average ratios of nickel to gallium of $28: 72$ atom $\%$ ( \pm 2 atom $\%$, Supporting Information File 1, Figure S5 top left, for individual values see Supporting Information File 1,
Table S2). The missing nickel from the initial equimolar ratio can be explained by the possible formation of $\mathrm{NiCp}^{*}$, which is stable up to $290{ }^{\circ} \mathrm{C}$ [49]. Quantification of the EDX spectrum of only the small particles shows an equimolar ratio of nickel to gallium of $52: 48$ atom $\%$ ( \pm 2 atom \%) (Supporting Information File 1, Figure S5, top right). Therefore, the small nanoparticles with a size distribution of $6 \pm 1 \mathrm{~nm}$ can be assigned to be $\mathrm{NiGa}$ nanoparticles. Moreover, the large particles with a size distribution of $90 \pm 20 \mathrm{~nm}$ can be assigned to be Ga-rich nanoparticles. We suggest that they cannot be pure $\mathrm{Ga}$ nanoparticles, because the low melting point of $\mathrm{Ga}$ metal of $30^{\circ} \mathrm{C}$, would yield liquid Ga metal under the energy of the electron beam in the TEM. Thus, the orthorhombic Ga phase probably contains a few percent of metallic nickel.

Similarly, $\mathrm{Ni}(\mathrm{COD})_{2}$ and $\mathrm{GaCp}^{*}$ were dispersed in equimolar ratio in $[\mathrm{BMIm}]\left[\mathrm{NTf}_{2}\right]$ for $12 \mathrm{~h}$ prior to the thermal decomposition. Through microwave irradiation at $230{ }^{\circ} \mathrm{C}$, a black powder was obtained after $30 \mathrm{~min}$. The TEM measurements show 

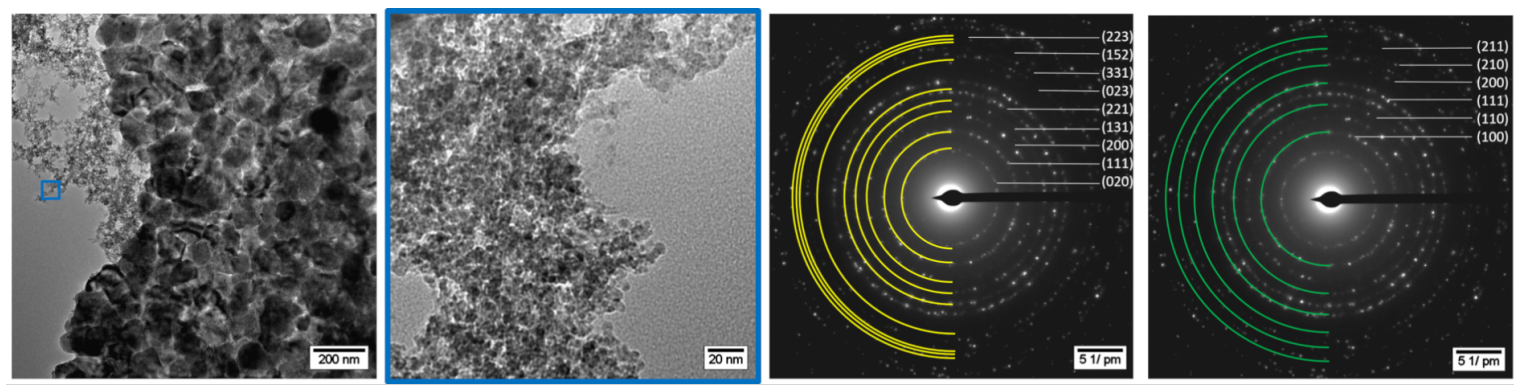

Figure 4: HRTEM images of NiGa nanoparticles (small particles) and Ga(Ni) nanoparticles (large particles) from a $0.5 \mathrm{wt} \%$ dispersion of $\mathrm{Ni}(\mathrm{COD})_{2}$ and $\mathrm{GaCp}^{*}$ in [BMIm] [NTf $\left.{ }_{2}\right]$ after $1 \mathrm{~h}$ of dispersion prior to $30 \mathrm{~min}$ of decomposition. SAED with indexed reflections for Ga (yellow diffraction rings for space group $\mathrm{Cmce}$ ) and $\mathrm{NiGa}$ (green diffraction rings for space group $\mathrm{Pm} \overline{3} \mathrm{~m}$ ).

spherical, crystalline and aggregated small nanoparticles with size distribution of $7 \pm 1 \mathrm{~nm}$ and large particles with a size distribution of $30 \pm 10 \mathrm{~nm}$ (Figure 5). As before, the corresponding SAED patterns show cubic NiGa for the small particles and orthorhombic $\mathrm{Ga}(\mathrm{Ni})$ for the large particles (Figure 5, space group: NiGa $P m \overline{3} m$, Ga: Cmce). The quantification of EDX spectra from three different spots on the TEM grid shows an averaged ratio of nickel to gallium of 38:62 atom \% ( \pm 1 atom $\%$ ) (for individual values see Supporting Information File 1, Table S2).
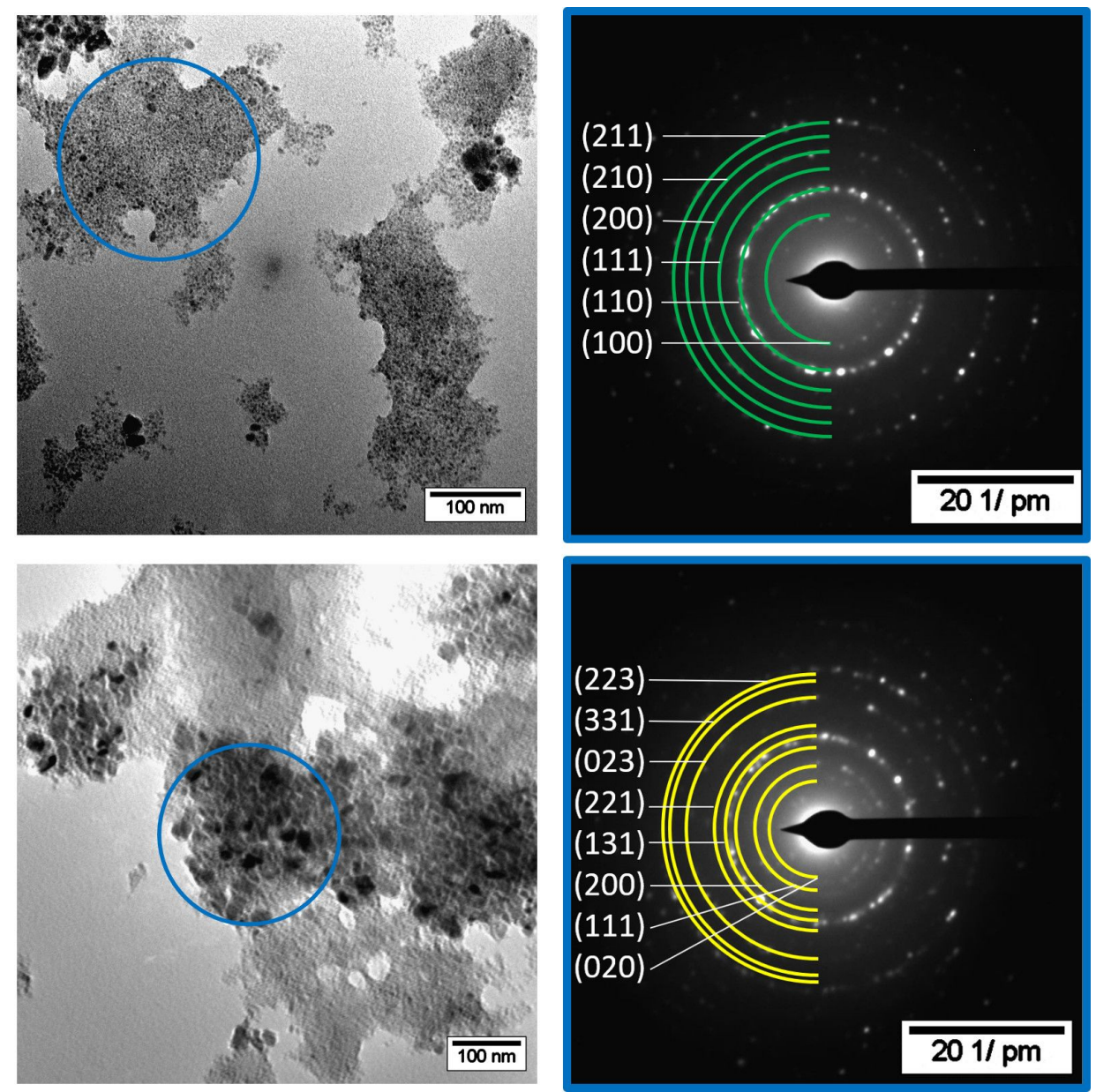

Figure 5: HRTEM images of NiGa nanoparticles (small particles) and Ga(Ni) nanoparticles (large particles) from a 1 wt $\%$ dispersion of $\mathrm{Ni}(\mathrm{COD})_{2}$ and $\mathrm{GaCp}^{*}$ in [BMIm][NTf ${ }_{2}$ after $12 \mathrm{~h}$ of dispersion and $30 \mathrm{~min}$ of decomposition. SAED with indexed reflections for NiGa (green diffraction rings for space group $P m \overline{3} m$ ) and $\mathrm{Ga}$ (yellow diffraction rings for space group $\mathrm{Cmce}$ ). 
By using high-resolution X-ray photoelectron spectroscopy (HRXPS), the electron binding energy of the $\mathrm{O} 1 \mathrm{~s}$ orbital was measured to confirm that the Ga nanoparticles in both samples are doped with $\mathrm{NiGa}$ and not with Ga oxide (Figure 6).
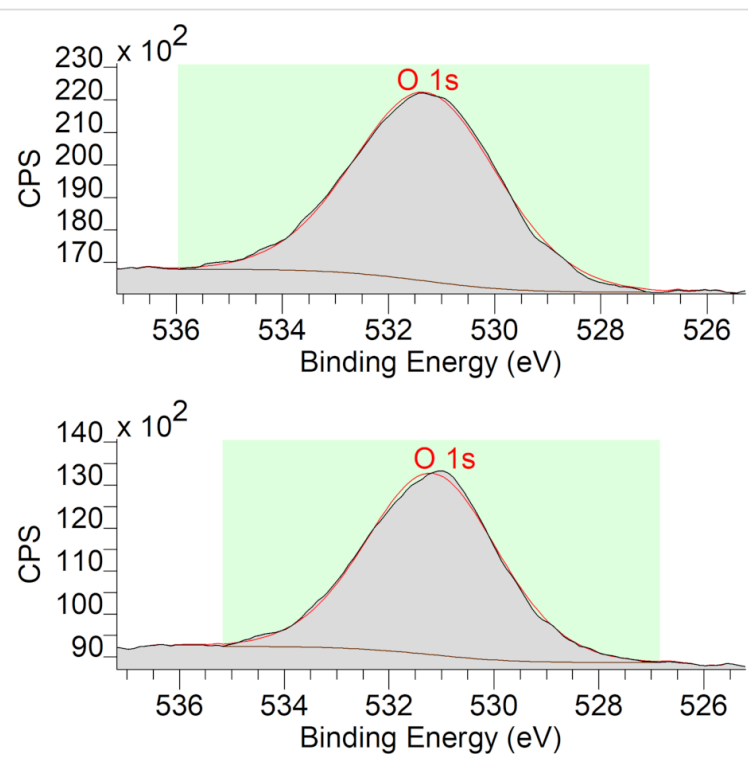

Figure 6: HRXPS region of the $\mathrm{O} 1 \mathrm{~s}$ orbital of $\mathrm{NiGa} / \mathrm{Ga}(\mathrm{Ni})$ nanoparticle samples obtained by microwave-induced decomposition after $1 \mathrm{~h}$ of dispersion time (top) and after $12 \mathrm{~h}$ of dispersion (bottom).

The concomitant Ga 2p $3 / 2$-peak (Supporting Information File 1, Figure S6) indicates only one Ga species, but we note that the binding energies of the different $\mathrm{Ga}$ oxidation states are within $1 \mathrm{eV}$ [50], which does not allow for an unequivocal assignment. The $\mathrm{O} 1 \mathrm{~s}$ peaks at $531.30 \mathrm{eV}$ and $531.18 \mathrm{eV}$ clearly show only the presence of organic oxygen and no metal oxides for which the binding energy would have to appear around 529-530 eV [50] (for full XP spectra see Figure S6).

The comparison of the samples after $1 \mathrm{~h}$ and $12 \mathrm{~h}$ of dispersion shows, that the size of the $\mathrm{Ga}(\mathrm{Ni})$ nanoparticles was reduced from $90 \pm 20 \mathrm{~nm}$ to $30 \pm 10 \mathrm{~nm}$, respectively (Figure 4 Figure 5). After the longer dispersion time the fraction of $\mathrm{NiGa}$ nanoparticles in the sample with $\mathrm{Ga}(\mathrm{Ni})$ particles increases. Evaluating the EDX spectra, the sample after $12 \mathrm{~h}$ of dispersion gave a nickel-to-gallium ratio of 38:62 atom \% ( \pm 1 atom $\%$ ), while the 1 hour-dispersion time sample was highly Ni deficient with a ratio of 28:72 atom \% ( \pm 2 atom \%). After $24 \mathrm{~h}$ of dispersion, the initial 1:1 ratio led to almost exclusively NiGa nanoparticles. Thus, a dispersion time of $24 \mathrm{~h}$ before microwave decomposition is needed to gain phase-pure $\mathrm{NiGa}$ nanoparticles without $\mathrm{Ga}(\mathrm{Ni})$ nanoparticles as by-products. We assume that during the dispersion a chemical reaction of the precursors to $\mathrm{Ni} / \mathrm{Ga}$ clusters occurs. The formation of clusters from metal precursor materials in ionic liquids has been described before, for example, [EMIm] $\left[\mathrm{Ni}\left(\mathrm{P}_{2} \mathrm{~S}_{8}\right)\right]$ [51], [BMMIm] ${ }_{16}\left[\mathrm{Sn}_{24} \mathrm{Se}_{56}\right]$ [52], [ $\left.\mathrm{Ru}_{2} \mathrm{Bi}_{14} \mathrm{Br}_{4}\right]\left[\mathrm{AlCl}_{4}\right]$ [53], [ $\left.\mathrm{Bi}_{5}\left(\mathrm{AlCl}_{4}\right)_{3}\right]$ [53], [ $\left.\mathrm{Au}\left(\mathrm{Bi}_{8}\right)\left(\mathrm{AlCl}_{4}\right)_{5}\right]$ [54], and $\left[\left(\mathrm{CuBi}_{8}\right)\left(\mathrm{AlCl}_{4}\right)\right][55]$

In organic solvents, organometallic Ni complexes, e.g., $\mathrm{Ni}(\mathrm{COD})_{2}$ and $\mathrm{Ni}(\mathrm{CO})_{4}$ are known to form different types of intermetallic clusters with $\mathrm{GaCp}^{*}$ and similar compounds, such as $\mathrm{Ni}(\mathrm{Cp} * \mathrm{Ga})(\mathrm{CO})_{3}, \mathrm{Ni}_{4}\left(\mathrm{Cp} \mathrm{p}^{*} \mathrm{Ga}\right)_{4}(\mathrm{CO})_{6}, \mathrm{Ni}\left(\mathrm{GaCp}^{*}\right)_{4}[46,56-$ $60]$. For example, the reaction of $\mathrm{Ni}(\mathrm{COD})_{2}$ with four equivalents of $\mathrm{GaCp}^{*}$ in $n$-hexane led to the formation of $\mathrm{Ni}\left(\mathrm{GaCp}^{*}\right)_{4}$ clusters [56]. Thus, the formation of such intermetallic clusters in ionic liquids is a working hypothesis for the required dispersion time of $24 \mathrm{~h}$.

To validate the formation of "large" Ga nanoparticles from $\mathrm{GaCp}^{*}$, despite its high decomposition temperature of approximately $300{ }^{\circ} \mathrm{C}$ [43], $\mathrm{GaCp}^{*}$ was dispersed in [BMIm] $\left[\mathrm{NTf}_{2}\right]$ for $24 \mathrm{~h}$ prior to thermal decomposition. Through microwave irradiation at $230{ }^{\circ} \mathrm{C}$, a grey powder was obtained after $30 \mathrm{~min}$. The TEM measurements show spherical, crystalline and aggregated nanoparticles with a size distribution of $350 \pm 100 \mathrm{~nm}$ (Figure 7).

The SAED-image confirms the formation of the orthorhombic Ga phase (space group: Cmce). Two additional reflections can be assigned to the two most intense ones of the $\mathrm{Ga}_{2} \mathrm{O}_{3}$ phase (space group: $R \overline{3} c h$ ). The TEM-EDX indicates a $\mathrm{Ga}(\mathrm{K}) / \mathrm{O}(\mathrm{K})$ ratio of 95:5 $\pm 4 \%$ (Figure 7 ). This ratio and the subsequent analyses by high-angle annular dark-field (HAADF)-scanning (S)TEM-EDX have to be interpreted very cautiously as EDX is not very well suited for the quantification of elements lighter than fluorine. HAADF-STEM images (Figure 8) were recorded in order to elucidate whether the presence of the oxygen is due to surface oxidation or whether the Ga nanoparticles contain $5 \%$ oxygen. An EDX line scan over different particles shows that there is probably no oxide shell around the Ga nanoparticles. Further analysis using EDX mapping also suggests that there is no Ga core-oxide shell structure. Instead, an even distribution of oxygen within the Ga nanoparticles was found (Figure 8).

Furthermore, the cyanoborate ionic liquids $[\mathrm{EMIm}]\left[\mathrm{B}(\mathrm{CN})_{4}\right]$ and $[\mathrm{EMIm}]\left[\mathrm{BF}(\mathrm{CN})_{3}\right]$ were tested as a reaction medium for the equimolar ratio of $\mathrm{Ni}(\mathrm{COD})_{2}$ and $\mathrm{GaCp}^{*}$ with short $(0.5$ or $1 \mathrm{~h}$ ) and long $(24 \mathrm{~h})$ dispersion times. Following microwave irradiation, TEM images show very different results (Figure 9). After $30 \mathrm{~min}$ of dispersion in $[\mathrm{EMIm}]\left[\mathrm{B}(\mathrm{CN})_{4}\right]$ non-aggregated $\mathrm{Ni}$ nanoparticles are formed with a size distribution of $4 \pm 1 \mathrm{~nm}$. EDX quantification from three different spots on the TEM grid showed only nickel (see Supporting Information File 1, 

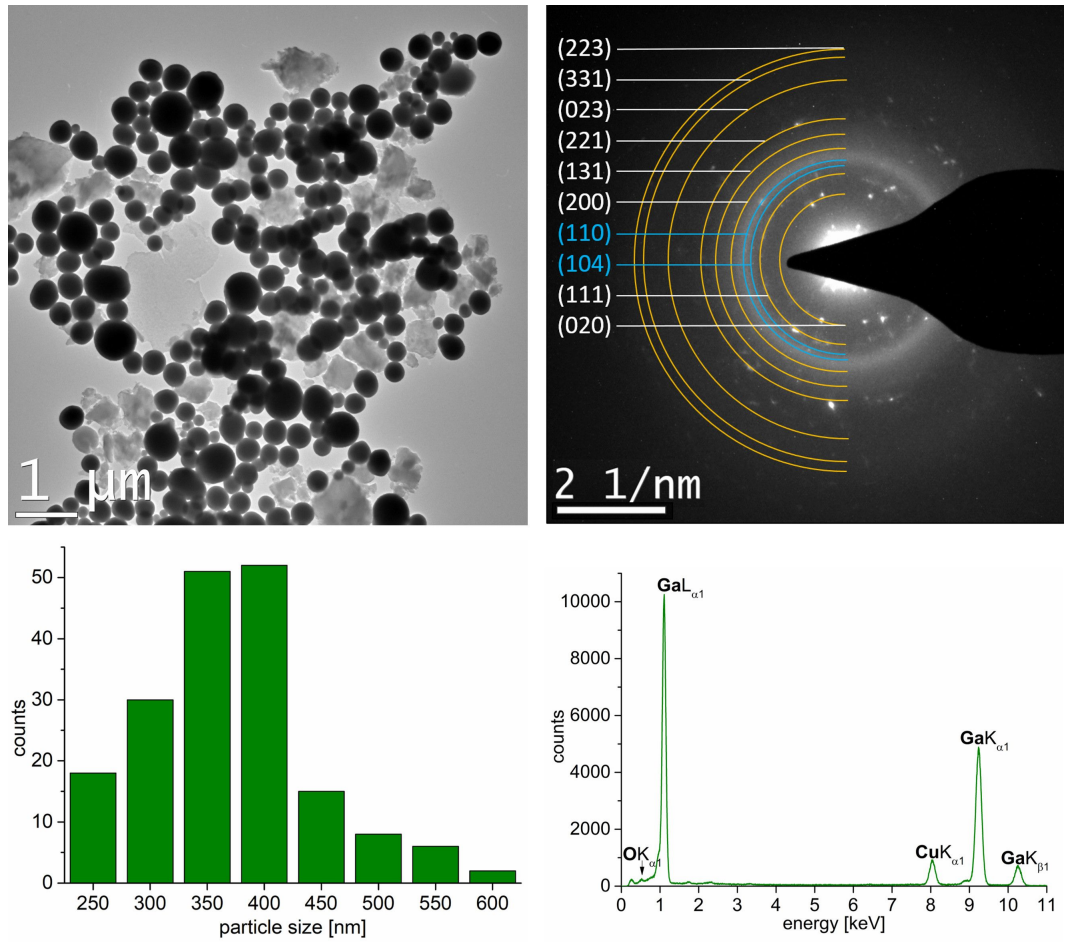

Figure 7: Top: HRTEM images of the $\mathrm{Ga}(\mathrm{O})$ nanoparticles from a $0.5 \mathrm{wt} \%$ dispersion of $\mathrm{GaCp}^{*}$ in $\left[\mathrm{BMIm]}\left[\mathrm{NTf}_{2}\right.\right.$ ] and SAED with indexed reflections for $\mathrm{Ga}$ (yellow diffraction rings for space group: $\mathrm{Cmce}$ ) and $\mathrm{Ga}_{2} \mathrm{O}_{3}$ (blue diffraction rings for space group: $R \overline{3} \mathrm{ch}$ ). Bottom: Particle size distribution of $350 \pm 100 \mathrm{~nm}$ (221 particles counted) and EDX spectrum.
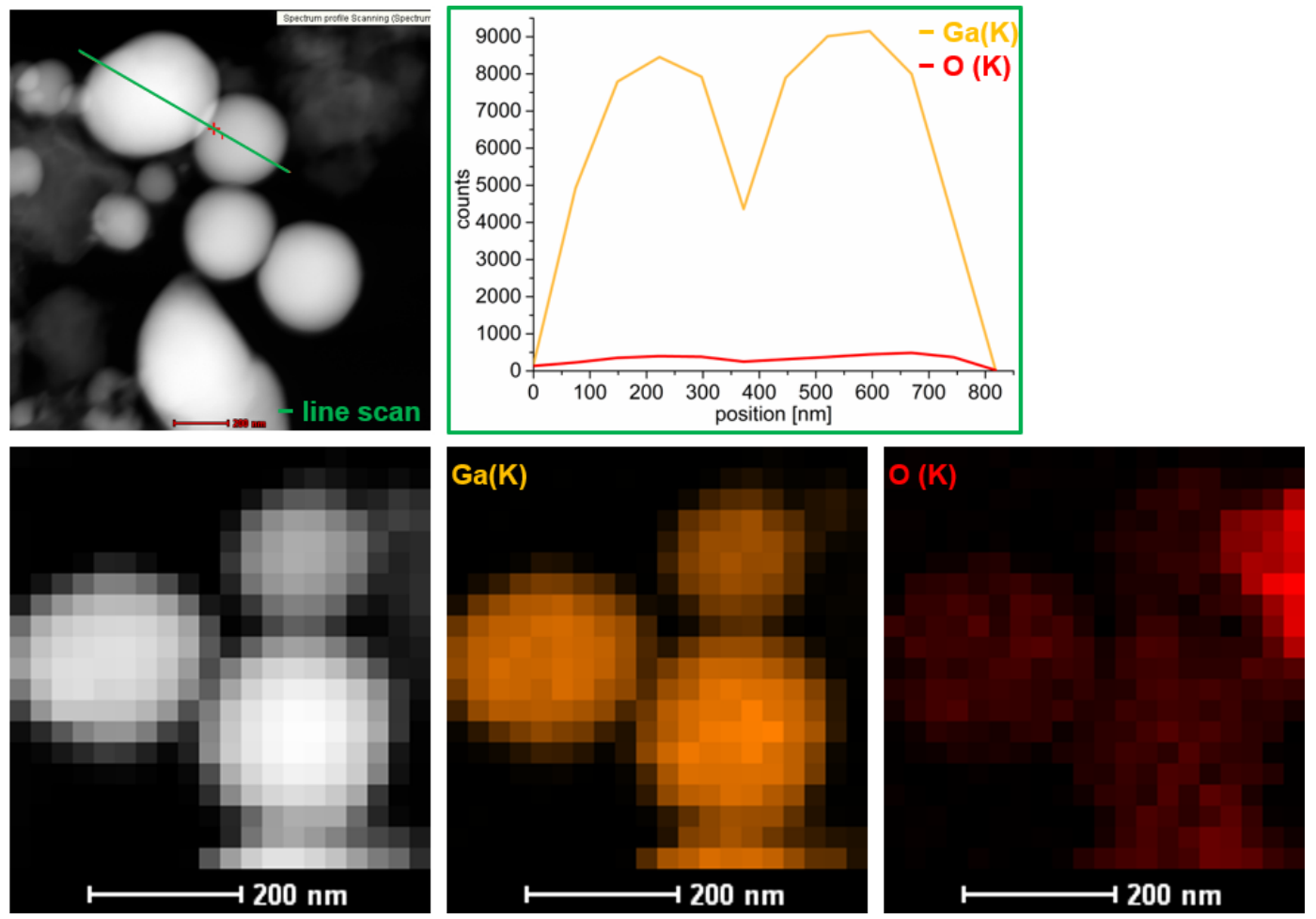

Figure 8: Top: HAADF-STEM images of $\mathrm{Ga}(\mathrm{O})$ nanoparticles from $0.5 \mathrm{wt} \%$ dispersion of $\mathrm{GaCp}^{*}$ in [BMIm][Ntf ${ }_{2}$. HAADF-STEM-EDX-line-scan (left, green line) with element counts $(\mathrm{Ga}(\mathrm{K})$ orange, $\mathrm{O}(\mathrm{K})$ red) depending on position (right). Bottom: HAADF-STEM-EDX-mapping: Ga $(\mathrm{K})$ orange, $\mathrm{O}(\mathrm{K})$ red. 

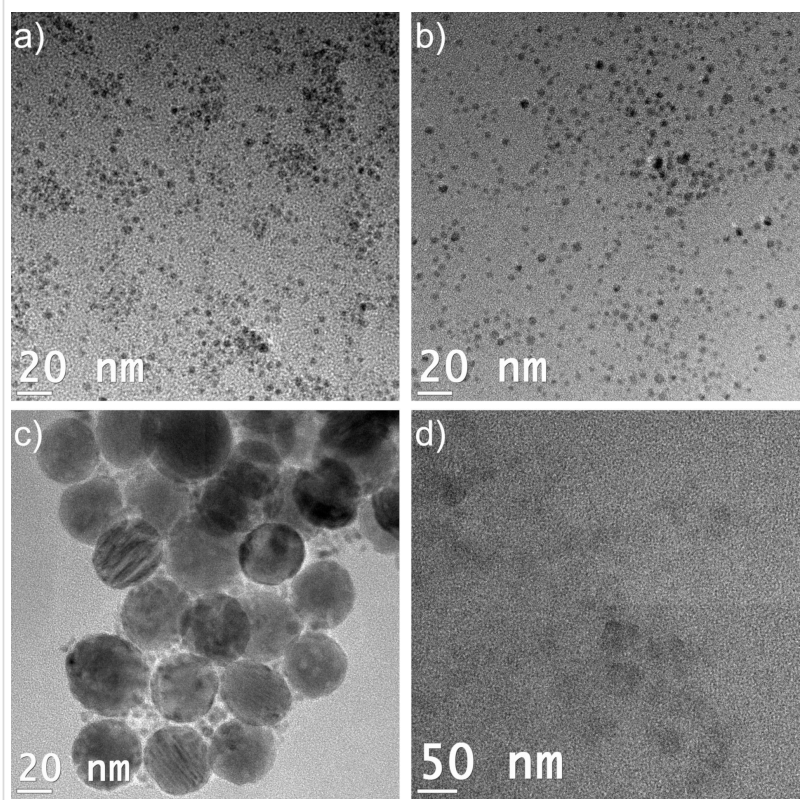

Figure 9: TEM images: a) Ni nanoparticles from $1 \mathrm{wt} \%$ dispersion of $\mathrm{Ni}(\mathrm{COD})_{2}$ and $\mathrm{GaCp}^{*}$ in $[\mathrm{EMIm}]\left[\mathrm{B}(\mathrm{CN})_{4}\right]$ after $30 \mathrm{~min}$ of dispersion and 30 min microwave-induced decomposition. For details of the particle size distribution of $4 \pm 1 \mathrm{~nm}$, see Supporting Information File 1, Figure S7. b) Ni/Ga nanoparticles from $1.5 \mathrm{wt} \%$ dispersion of $\mathrm{Ni}(\mathrm{COD})_{2}$ and $\mathrm{GaCp}^{*}$ in $[\mathrm{EMIm}]\left[\mathrm{B}(\mathrm{CN})_{4}\right]$ after $24 \mathrm{~h}$ of dispersion and $30 \mathrm{~min}$ of microwave-induced decomposition. For details of the particle size distribution of $4 \pm 1 \mathrm{~nm}$, see Supporting Information File 1, Figure S8. c) $\mathrm{Ni}$ and $\mathrm{Ga}$ nanoparticles from $1 \mathrm{wt} \%$ dispersion of $\mathrm{Ni}(\mathrm{COD})_{2}$ and $\mathrm{GaCp} *$ in [EMIm] $\left[\mathrm{BF}(\mathrm{CN})_{3}\right]$ after $1 \mathrm{~h}$ of dispersion time and $30 \mathrm{~min}$ of microwave-induced decomposition. . For details of the particle size distribution of nickel with $5 \pm 1 \mathrm{~nm}$ and of gallium with $40 \pm 5 \mathrm{~nm}$, see Supporting Information File 1, Figure S9 and Figure S10. d) No nanoparticle formation in [EMIm] $\left[\mathrm{FB}(\mathrm{CN})_{3}\right]$ from $\mathrm{Ni}(\mathrm{COD})_{2}$ and $\mathrm{GaCp}^{*}$ after $24 \mathrm{~h}$ of dispersion and $30 \mathrm{~min}$ of microwave-induced decomposition.

Figure S7). After $24 \mathrm{~h}$ of dispersion in [EMIm] $\left[\mathrm{B}(\mathrm{CN})_{4}\right]$ non-aggregated $\mathrm{Ni} / \mathrm{Ga}$ nanoparticles are formed with a size distribution of $4 \pm 1 \mathrm{~nm}$. EDX quantification showed a ratio of nickel to gallium of 38:62 atom \% ( \pm 2 atom \%) (see Supporting Information File 1, Figure S8). In both cases no SAED measurement was possible. In contrast, after $1 \mathrm{~h}$ of dispersion in $[\mathrm{EMIm}]\left[\mathrm{BF}(\mathrm{CN})_{3}\right]$ TEM images showed crystalline particles with two different sizes. The small particles had a size distribution of $5 \pm 1 \mathrm{~nm}$ and the large particles had a size distribution of $40 \pm 5 \mathrm{~nm}$. Through EDX quantification and SAED measurements the small particles were matched to hexagonal $\mathrm{Ni}$ $\left(P 6_{3} / m m c\right)$ and the large particles were matched to cubic $\mathrm{Ga}$ $(I 4 \overline{3} d$ ) (see Supporting Information File 1, Figure S9 and Figure S10). After $24 \mathrm{~h}$ of dispersion in [EMIm] $\left[\mathrm{BF}(\mathrm{CN})_{3}\right]$ no nanoparticle formation was observed.

\section{Catalysis}

Previously reported $\mathrm{NiGa}$ nanoparticles synthesized in $[\mathrm{BMIm}]\left[\mathrm{BF}_{4}\right]$ with a size distribution of $14 \pm 5 \mathrm{~nm}$ were used successfully in the semihydrogenation reaction of the terminal alkyne 1-octyne and the internal alkyne diphenylacetylene, with yields of $90 \%$ and selectivities of $94 \%$ and $87 \%$, respectively. In this previous work $2 \mathrm{~g}$ of the alkyne substrate were mixed with $0.1 \mathrm{~g}$ of a 0.5 wt \% NiGa@[BMIm] $\left[\mathrm{BF}_{4}\right]$ dispersion (containing $3.9 \mu \mathrm{mol} \mathrm{NiGa)}$ in a steel autoclave. Hydrogen was charged with 5 bar at $120{ }^{\circ} \mathrm{C}$ and the reaction was run for $3 \mathrm{~h}$ [30]. For comparison, the catalysis with NiGa@[BMIm] $\left[\mathrm{NTf}_{2}\right]$ was carried out under analogous reaction conditions in the semihydrogenation reaction of the internal alkyne 4-octyne (see below Scheme in Table 2).

A linear increase of hydrogen consumption is seen in Figure 10. After three hours no plateau value was reached, and the reaction was stopped as the hydrogen consumption was still well below the expected 0.018 mol for a quantitative semihydrogenation. The catalyst was recycled over five runs. In all runs,
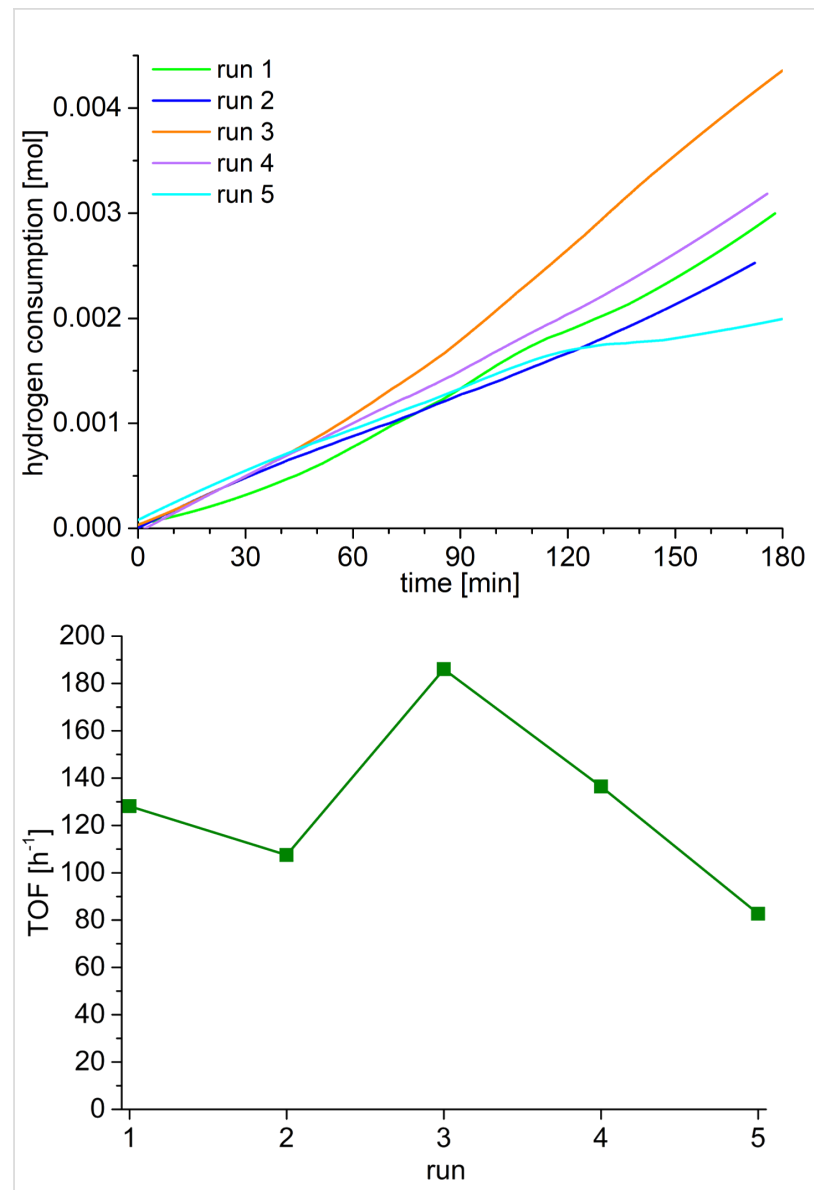

Figure 10: Top: Hydrogen uptake as a function of the time for the semihydrogenation of $0.018 \mathrm{~mol} 4$-octyne $(2 \mathrm{~g}, 2.7 \mathrm{~mL})$ using $0.1 \mathrm{~g} \mathrm{NiGa@[BMIm]}\left[\mathrm{NTf}_{2}\right]$ dispersion $(1 \mathrm{wt} \%=0.001 \mathrm{~g}$ in total metal, $7.8 \mu \mathrm{mol} \mathrm{NiGa}$ ) as catalyst at a $4-$ octyne/metal ratio of $1: 2331,150{ }^{\circ} \mathrm{C}$, 5 bar $\mathrm{H}_{2}, 3 \mathrm{~h}$. A $100 \%$ conversion corresponds to an $\mathrm{H}_{2}$ uptake of $0.018 \mathrm{~mol}(36 \mathrm{mg}, 403 \mathrm{~mL})$. Bottom: TOF $\left[\mathrm{h}^{-1}\right.$ ] per run $\left(\mathrm{TOF}=\mathrm{mol}_{\text {substrate }} /\left(\mathrm{mol}_{\text {catalyst }}\right.\right.$ time $)$ ). 
conversions stayed below 20\% (Table 1). TOF values are between $83-186 \mathrm{~h}^{-1}$ reaching the highest value at the third run (Figure 10, Table 1).

GC-MS-analysis showed a $100 \%$ selectivity towards (E)-4octene in all runs with the NiGa nanoparticles (Table 2).

Utilizing clusters like $[\mathrm{Cp} * \mathrm{Ru}(\mathrm{COD}) \mathrm{Cl}]$ in catalytic semihydrogenation reactions, the formation of only $(E)$ - [61-63] or (Z)$[64,65]$ derivates are equally known [66]. When metal nanoparticles like the Lindlar catalyst $\mathrm{PdPb} @ \mathrm{CaCO}_{3}$ are used, the formation of (Z)-alkenes [67-71] is favored. For the formation of (E)-alkenes the use of a tandem catalytic system $\mathrm{Pd}_{3} \mathrm{~Pb} @ \mathrm{SiO}_{2}+$ $\mathrm{RhSb} @ \mathrm{SiO}_{2}$ [72] is needed. Catalytic semihydrogenation of internal alkynes favors the formation of $(Z)$-alkenes because of their syn-addition style. However, after the initial formation of the $Z$-alkenes, through isomerization reactions the thermodynamically more stable $(E)$-alkenes can be obtained [65,73]. In the literature, the semihydrogenation reaction of the internal alkyne diphenylacetylene with $\mathrm{NiGa@[BMIm]}\left[\mathrm{BF}_{4}\right]$ led to the formation of a $Z / E$-mixture of diphenylethene [30].

During catalysis with nanoparticles in ionic liquids a two-phase system is often formed with the nanoparticles suspended in the denser ionic liquid in the lower phase and the organic substrate in the upper phase. Studies have shown that catalyses in ionic liquids are slower due to diffusion limitations and, thus, lower conversion rates are obtained than in solventless systems [61]. Still, catalysis in ionic liquids achieves the same selectivities. Also, the IL prevents nanoparticle agglomeration to allow for catalyst recycling over several runs [61]. To examine the influence of the ionic liquid, the reaction was repeated under solventless conditions with precipitated, largely IL-free NiGa nanoparticles. The NiGa nanoparticles were precipitated from the IL with acetonitrile and the IL was removed as much as possible by washing with acetonitrile (see Supporting Information File 1, Figure S11). The precipitated NiGa nanoparticles exhibited over three runs very high conversion rates of $82-96 \%$ (Table 3).

After 30 min the hydrogen consumption reaches a plateau at an $\mathrm{H}_{2}$ uptake value that typically corresponds to over $90 \%$ conversion (Figure 11, Table 3).

The selectivity towards the alkene still remains near $90 \%$ and can approach $100 \%$ (Table 4). Taking a closer look at the GC-MS results, E/Z-selectivity of 4-octene can be distinguished, as well as a bond-shift isomerization reaction to $E / Z-3-$ octene. Bond-shift isomerization reactions towards 3-octene are dominant in the first run. In this first run also a 1:0.73 $\mathrm{mol} / \mathrm{mol}$

\begin{tabular}{|c|c|c|c|c|c|c|}
\hline & run $1 \mathrm{a}$ & run $1 b^{b}$ & run $2 b$ & run $2 b$ & run $4 b$ & run $5 b$ \\
\hline conversion & $15 \%$ & $19 \%$ & $10 \%$ & $20 \%$ & $13 \%$ & $5 \%$ \\
\hline TOF & $103 h^{-1}$ & $128 h^{-1}$ & $107 \mathrm{~h}^{-1}$ & $186 h^{-1}$ & $136 h^{-1}$ & $83 h^{-1}$ \\
\hline
\end{tabular}

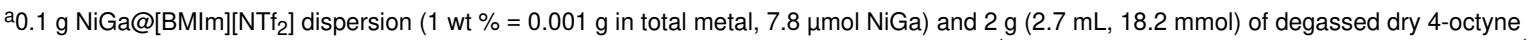
(molar NiGa/substrate ratio $=1: 2331$ ) were stirred under 5 bar $\mathrm{H}_{2}$ at $120{ }^{\circ} \mathrm{C}$ for $3 \mathrm{~h}$. TOF $\left[\mathrm{h}^{-1}\right]$ per run $\left(\mathrm{TOF}=\mathrm{mol}_{\text {substrate }} /\left(\mathrm{mol}_{\mathrm{catalyst}} \cdot \mathrm{time}\right)\right.$ ). ${ }^{\mathrm{b}} \mathrm{Runs}$ $1 \mathrm{~b}-5 \mathrm{~b}$ were carried out with the same catalyst by removing the products in high vacuum.

Table 2: Selectivities of the semihydrogenation of 4-octyne to 4-octene using NiGa@[BMIm][NTf $]^{\mathrm{a}}{ }^{\mathrm{a}}$

\begin{tabular}{|c|c|c|c|c|c|c|}
\hline & run $1 \mathrm{a}$ & run $1 b^{b}$ & run $2 b$ & run $2 b$ & run $4 b$ & run $5 b$ \\
\hline$(E)$-4-ene & $100 \%$ & $100 \%$ & $100 \%$ & $100 \%$ & $100 \%$ & $100 \%$ \\
\hline (Z)-4-ene & $0 \%$ & $0 \%$ & $0 \%$ & $0 \%$ & $0 \%$ & $0 \%$ \\
\hline$n$-octane & $0 \%$ & $0 \%$ & $0 \%$ & $0 \%$ & $0 \%$ & $0 \%$ \\
\hline
\end{tabular}

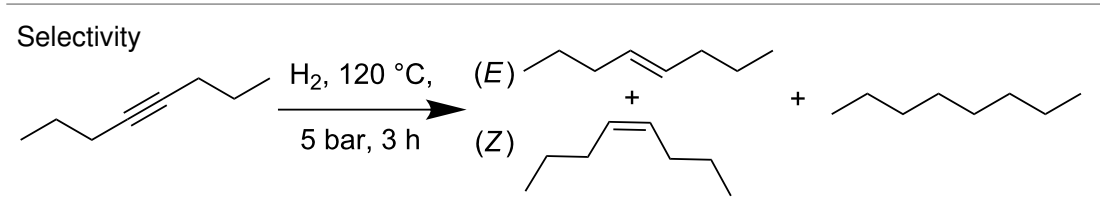

${ }^{\mathrm{a}} 0.1 \mathrm{~g} \mathrm{NiGa@[BMIm][NTf}$ ] dispersion $(1 \mathrm{wt} \%=0.001 \mathrm{~g}$ in total metal, $7.8 \mu \mathrm{mol} \mathrm{NiGa})$ and $2 \mathrm{~g}(2.7 \mathrm{~mL}, 18.2 \mathrm{mmol})$ of degassed dry 4-octyne

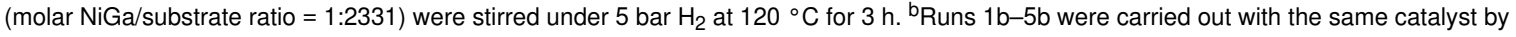
removing the products in high vacuum. 


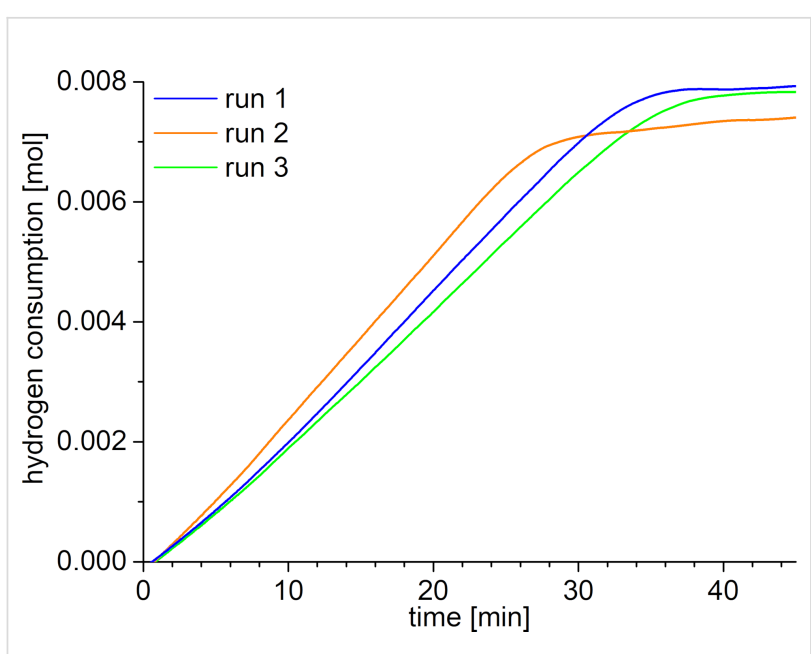

Figure 11: Hydrogen uptake as a function of the time for the semihydrogenation of $0.009 \mathrm{~mol} 4$-octyne $(1 \mathrm{~g}, 1.35 \mathrm{~mL})$ using $10 \mathrm{mg}$ precipitated, IL-free precipitated NiGa nanoparticles $(77 \mu \mathrm{mol} \mathrm{NiGa})$ as catalyst at a 4-octyne/metal ratio of $1: 115,150{ }^{\circ} \mathrm{C}, 5$ bar $\mathrm{H}_{2}$. A $100 \%$ conversion corresponds to an $\mathrm{H}_{2}$ uptake of $0.009 \mathrm{~mol}$ (18 mg, $202 \mathrm{~mL})$.

Table 3: Semihydrogenation of 4-octyne to 4-octene using precipitated IL-free NiGa nanoparticles. ${ }^{a}$

\begin{tabular}{llll} 
& run 1 & run 2 & run 3 \\
\hline conversion $^{b}$ & $93-96 \%$ & $92-93 \%$ & $82-92 \%$ \\
TOF & $170 \mathrm{~h}^{-1}$ & $211 \mathrm{~h}^{-1}$ & $154 \mathrm{~h}^{-1}$ \\
\hline
\end{tabular}

a10 mg precipitated, IL-free NiGa nanoparticles $(77 \mu \mathrm{mol})$ and $1 \mathrm{~g}$ (1.35 mL, $9 \mathrm{mmol}$ ) of degassed dry 4-octyne (molar NiGa/substrate ratio $=1: 115$ ) were stirred under 5 bar $\mathrm{H}_{2}$ at $120^{\circ} \mathrm{C}$. Runs $1-3$ were carried out with the same catalyst by removing the products in high vacuum. TOF $\left[\mathrm{h}^{-1}\right]$ per run $\left(\mathrm{TOF}=\mathrm{mol}_{\text {substrate }} /\left(\mathrm{mol}_{\text {catalyst }} \cdot\right.\right.$ time $)$ ). ${ }^{b}$ Runs 1-3 were carried out twice with the same catalyst by removing the products in high vacuum. For each of the two runs the conversion values are given.
$E / Z$-mixture of 4-octene was formed. In the second and third run, $E$-4-octene was the predominant product.

In comparison, precipitated $\mathrm{NiGa}$ nanoparticles have higher TOF values as NiGa @[BMIm][NTf 2 (compare Table 1 and Table 3, Supporting Information File 1, Table S3). TOF values are slightly increased for precipitated, IL-free NiGa nanoparticles.

To determine whether the precipitated NiGa nanoparticles used in the catalytic reaction change over time HRTEM images are measured (Figure 12). After three runs, the particles are more agglomerated, but their size distribution did not change. Particles are still at a size of $5 \pm 1 \mathrm{~nm}$.

\section{Conclusion}

After $24 \mathrm{~h}$ of dispersion of all-hydrocarbon precursors $\mathrm{Ni}(\mathrm{COD})_{2}$ and $\mathrm{GaCp}^{*}$ in the ionic liquid [BMIm] $\left[\mathrm{NTf}_{2}\right.$ ], microwave-induced co-decomposition yielded phase-pure $\mathrm{NiGa}$ nanoparticles of $5 \pm 1 \mathrm{~nm}$. In order to gain crystalline $\mathrm{NiGa}$ nanoparticles, $30 \mathrm{~min}$ of microwave-induced decomposition were found to be required. With dispersion times of 1 or $12 \mathrm{~h}$ before the microwave-induced decomposition, $\mathrm{Ga}(\mathrm{Ni})$ nanoparticles were formed as a by-product to NiGa nanoparticles. To complete this investigation, $\mathrm{GaCp} *$ was successfully decomposed in [BMIm] $\left[\mathrm{NTf}_{2}\right]$ to $\mathrm{Ga}_{2} \mathrm{O}_{3}$-doped $\mathrm{Ga}$ particles with a size of $350 \pm 100 \mathrm{~nm}$. The formation of core-shell sparticles can be ruled out by HRTEM/STEM-EDX-measurements.

Phase-pure NiGa nanoparticles were tested in the semihydrogenation of an internal alkyne. A comparison study between $\mathrm{NiGa}$ nanoparticles in ionic liquid and precipitated $\mathrm{NiGa}$ nanoparticles under solventless conditions was performed. $\mathrm{NiGa} @[\mathrm{BMIm}]\left[\mathrm{NTf}_{2}\right]$ catalyzed the hydrogenation of the

Table 4: Selectivities of the semihydrogenation of 4-octyne to 4-octene using precipitated, IL-free NiGa nanoparticles. ${ }^{\text {a }}$

\begin{tabular}{|c|c|c|c|}
\hline & run 1 & run 2 & run 3 \\
\hline$(E)$-4-ene ${ }^{b}$ & $46-48 \%$ & $87-92 \%$ & $82-88 \%$ \\
\hline$(Z)$-4-ene ${ }^{b}$ & $32-34 \%$ & $0 \%$ & $0 \%$ \\
\hline$(E)$-3-ene ${ }^{\mathrm{b}}$ & $4-6 \%$ & $0 \%$ & $0 \%$ \\
\hline$(Z)-3$-ene $e^{b}$ & $7-12 \%$ & $0-5 \%$ & $0-4 \%$ \\
\hline n-octane & $0 \%$ & $0 \%$ & $0 \%$ \\
\hline
\end{tabular}

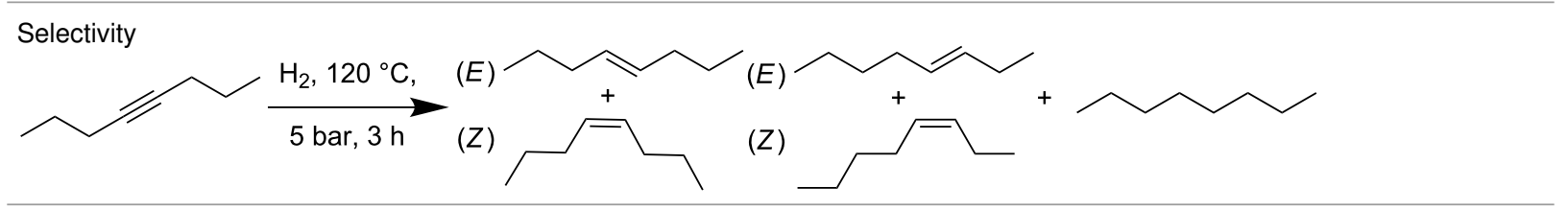

a $10 \mathrm{mg}$ precipitated, IL-free NiGa nanoparticles $(77 \mu \mathrm{mol})$ and $1 \mathrm{~g}(1.35 \mathrm{~mL}, 9 \mathrm{mmol})$ of degassed dry 4-octyne (molar NiGa/substrate ratio $=1: 115)$ were stirred under 5 bar $\mathrm{H}_{2}$ at $120^{\circ} \mathrm{C}$. Runs $1-3$ were carried out with the same catalyst by removing the products in high vacuum. ${ }^{\mathrm{b}} \mathrm{Runs} 1-3$ were carried out twice with the same catalyst by removing the products in high vacuum. For each of the two runs the composition values are given. 

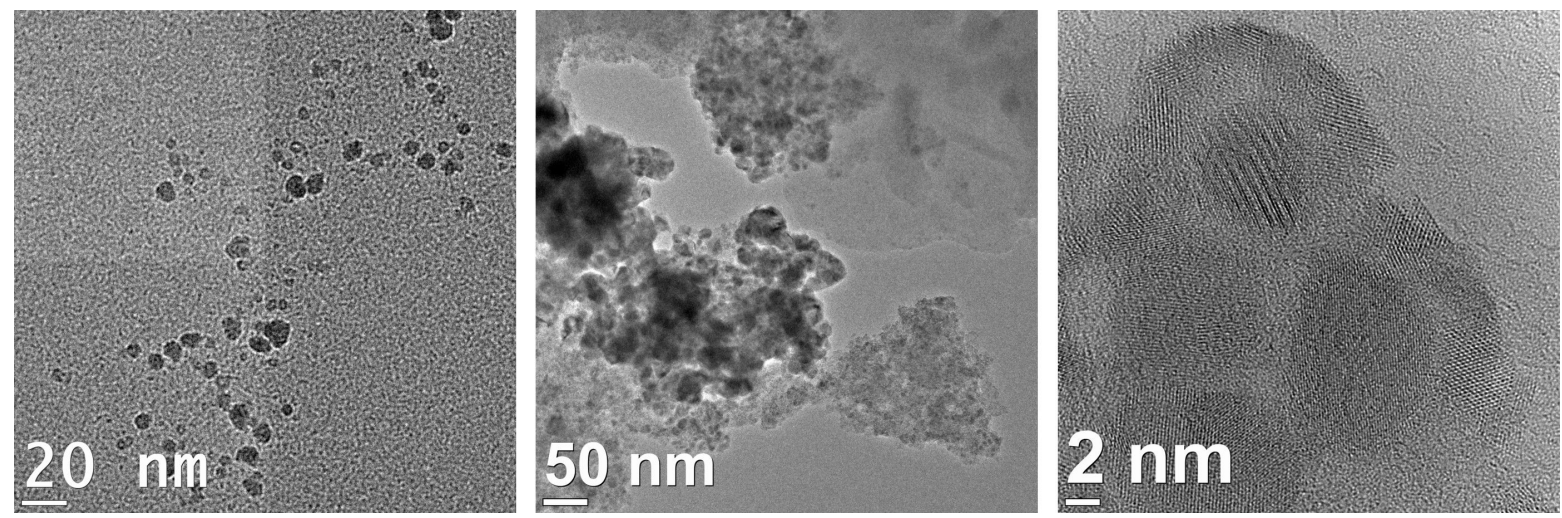

Figure 12: HRTEM image of precipitated NiGa nanoparticles before the catalysis (left) and highly agglomerated NiGa nanoparticles after the catalysis (middle and right).

internal alkyne 4-octyne with $100 \%$ selectivity towards $E$-4octene over 5 runs, but with poor conversions. After the removal of the IL, precipitated NiGa nanoparticles achieved an increased conversion higher than $90 \%$ over 3 runs. The selectivities towards the alkene still reached $100 \%$.

\section{Experimental}

Due to the sensitivity of the precursor substances towards hydrolysis and oxidation, that is, moisture and oxygen (air), all experiments were carried out in a purified argon or nitrogen atmosphere by using standard Schlenk techniques. Samples were prepared and stored in an MBraun Glovebox. Solvents (acetonitrile, $n$-hexane, and methylene chloride) were dried by using an MBraun solvent purification system or $4 \AA$ molecular sieves (1-methylimidazole, 1-chlorobutane) and stored over $4 \AA$ molecular sieves in a nitrogen atmosphere. Remaining water contents of the solvents were measured by a coulometric KarlFischer titration (ECH/ANALYTIK JENA AQUA 40.00) and did not exceed $10 \mathrm{ppm}$.

$\mathrm{Ni}(\mathrm{COD})_{2}$ was purchased from $\mathrm{ABCR}$, stored at $-4{ }^{\circ} \mathrm{C}$ and used without further purification. $\mathrm{GaCp}^{*}$ was synthesized according to literature under strictly inert dry argon conditions [69]. The ionic liquid [BMIm] $\left[\mathrm{NTf}_{2}\right]$ was synthesized according to the literature by reacting 1-methylimidazole with 1-chlorobutane to yield first $[\mathrm{BMIm}][\mathrm{Cl}]$, which was further reacted with $\mathrm{LiNTf}_{2}$ to give [BMIm][NTf $][74,75]$. The IL was dried under ultra-high vacuum $\left(10^{-7} \mathrm{mbar}\right)$ at $80{ }^{\circ} \mathrm{C}$ for three days. $[\mathrm{EMIm}]\left[\mathrm{B}(\mathrm{CN})_{4}\right]$ and $[\mathrm{EMIm}]\left[\mathrm{BF}(\mathrm{CN})_{3}\right]$ was synthesized similarly by metathesis reaction of $[\mathrm{EMIm}][\mathrm{Br}]$ with $\mathrm{K}\left[\mathrm{B}(\mathrm{CN})_{4}\right]$ and $\mathrm{K}\left[\mathrm{BF}(\mathrm{CN})_{3}\right]$, respectively [76,77]. Propylene carbonate was dried over $4 \AA$ molecular sieves for several days. Characterization was carried out by ${ }^{1} \mathrm{H}$ and ${ }^{13} \mathrm{C}$ NMR spectroscopy. Quantitative anion exchange and IL purity of $99.9 \%$ was assessed by ion chromatography (Dionex ICS-1100, with
IonPac ${ }^{\circledR} \mathrm{AS} 22,4 \times 250 \mathrm{~mm}$ column). The water content measured by coulometric Karl-Fischer titration was below $10 \mathrm{ppm}$.

Powder X-ray diffraction. PXRD data were obtained at ambient temperature on a Bruker D2 Phaser using a flat sample holder and $\mathrm{Cu} \mathrm{K} \alpha$ radiation $(\lambda=1.54182 \AA$, $35 \mathrm{kV})$. Samples had been precipitated with acetonitrile from the nanoparticle/IL dispersion and washed several times with acetonitrile. PXRDs were measured for $1 \mathrm{~h}$.

Transmission electron microscopy. TEM was performed with a FEI Tecnai G2 F20 electron microscope [78] operated at $200 \mathrm{kV}$ accelerating voltage, with a FEI Titan 80-300 TEM operated at $300 \mathrm{kV}$ accelerating voltage [79] or with a Philips CM20 operated at $200 \mathrm{kV}$ accelerating voltage. Conventional TEM images were recorded with a Gatan UltraScan 1000P detector.

Energy-dispersive $X$-ray spectroscopy. EDX spectra for elemental (metal) analysis were recorded using an exposure time of 3 min. High-angle annular dark-field scanning transmission electron microscopy (HAADF-STEM) was also performed with the FEI Tecnai G2 F20 electron microscope. All EDX spectra acquired in STEM mode were averaged scans over selected areas of about $100 \times 100 \mathrm{~nm}^{2}$. The EDX spectra of an isolated particle were measured at several points with a spatial resolution of $1 \mathrm{~nm}^{2}$ (acquisition time of $30 \mathrm{~s}$ at each point). The instrumental errors of this high-resolution EDX scan led to an estimated standard deviation of $10-15 \%$ relative error. TEM samples were prepared by drop-casting the diluted material on $200 \mu \mathrm{m}$ carbon-coated copper or gold grids. The size distribution was determined manually or with the aid of the Gatan Digital Micrograph software from at least 50 individual particles. 
Selected-area electron diffraction (SAED) patterns have been recorded with the above mentioned TEM instruments. The area selection was achieved with a round aperture moved in the first intermediate image plane with a corresponding diameter of $0.64 \mu \mathrm{m}$ in the object plane. For each acquisition a sample region with a significant amount of material was placed inside the aperture. The objected was illuminated with a wide-spread parallel beam obtaining focused diffraction patterns. The diffraction images were calibrated with Debye-Scherrer patterns recorded from a gold reference sample (S106, Plano GmbH, Wetzlar, Germany).

High-resolution X-ray photoelectron spectroscopy, HRXPS(ESCA-) measurements were performed with a Fisons/VG Scientific ESCALAB 200X XP-spectrometer, operating at $70-80^{\circ} \mathrm{C}$, a pressure of $7.0 \times 10^{-9}$ bar and a sample angle of $33^{\circ}$. Spectra were recorded using polychromatic Al K $\alpha$ excitation $(11 \mathrm{kV}, 20 \mathrm{~mA})$ and an emission angle of $0^{\circ}$. Calibration of the XPS was carried out by recording spectra with Al K $\alpha$ $\mathrm{X}$-rays from clean samples of copper, silver and gold at $50 \mathrm{eV}$ and $10 \mathrm{eV}$ pass energy and comparison with reference values. Spectra were obtained with an Al K $\alpha$ X-ray source, using C 1s as a reference for the binding energy [50].

Gas chromatography-mass spectrometry (GC-MS) data were recorded on a Thermo Finnigan Trace DSQ (Shimadzu GC2014, column Ultra2, crosslinked 5\% PhMe silicone, $25 \mathrm{~m} \times 0.2 \mathrm{~mm} \times 11 \mathrm{~mm}$ ).

\section{Preparation of nanoparticles in ionic liquid}

Syntheses of Ni/Ga nanoparticles were prepared in septumsealed $10 \mathrm{~mL}$ CEM microwave-vials in a CEM Discover microwave under argon atmosphere. $\mathrm{Ni}(\mathrm{COD})_{2}$ and $\mathrm{GaCp}$ * were suspended for a chosen time ( $30 \mathrm{~min}, 1 \mathrm{~h}, 12 \mathrm{~h}$ or $24 \mathrm{~h}$ ) in the dried and desoxygenated IL or PC before microwave decomposition to gain $0.5-1.5 \mathrm{wt} \%$ dispersion of the nanoparticles. All precursor dispersions were decomposed at a power of $50 \mathrm{~W}$ to a temperature of $230{ }^{\circ} \mathrm{C}$ for a chosen time $(10 \mathrm{~min}, 20 \mathrm{~min}$, $30 \mathrm{~min}$ ). For specific mass values, dispersion and decomposition times see Supporting Information File 1, Table S4. In the case of $\mathrm{Ga}(\mathrm{O})$ nanoparticles in $[\mathrm{BMIm}]\left[\mathrm{NTf}_{2}\right] \mathrm{GaCp}^{*}(15.6 \mathrm{mg}$, $0.076 \mathrm{mmol}$ ) was suspended for $24 \mathrm{~h}$ in the dried and desoxygenated $[\mathrm{BMIm}]\left[\mathrm{NTf}_{2}\right]\left(1 \mathrm{~g}, 0.71 \mathrm{~mL}\right.$, density $\left.=1.41 \mathrm{~g} / \mathrm{cm}^{3}\right)$ before microwave decomposition $\left(60 \mathrm{~min}, 50 \mathrm{~W}, 230{ }^{\circ} \mathrm{C}\right)$ to gain 0.5 wt \% nanoparticles in ionic liquid.

\section{Catalytic hydrogenation of alkynes}

A Büchi stainless steel autoclave with a glass inlet was charged with $0.1 \mathrm{~g}$ of freshly synthesized $\mathrm{NiGa} @[\mathrm{BMIm}]\left[\mathrm{NTf}_{2}\right]$ dispersion ( $1 \mathrm{wt} \%$ in total metal, $8 \mu \mathrm{mol} \mathrm{NiGa).} 2 \mathrm{~g}$ of degassed, dry substrate 4-octyne $(2.7 \mathrm{~mL}, 18.2 \mathrm{mmol})$ was added. For the hydrogenation without ionic liquid $10 \mathrm{mg}$ precipitated $\mathrm{NiGa}$ nanoparticles $(0.86 \mathrm{mmol})$ were mixed with $1 \mathrm{~g}$ of degassed, dry substrate 4-octyne $(1.3 \mathrm{~mL}, 9.1 \mathrm{mmol})$. The reaction mixture was heated to $120^{\circ} \mathrm{C}$. After reaching the reaction temperature, the autoclave was pressurized with 5 bar $\mathrm{H}_{2}$ (Büchi press flow gas controller, bpc), which was kept constant by the Büchi bpc. After reaching a plateau value or after a maximum time of $3 \mathrm{~h}$ the reaction was stopped, the autoclave was cooled down and a $0.5 \mathrm{~g}$ sample was analyzed for its content by GC/MS and NMR. Conversion and selectivity were determined by GC/MS [retention times in min: 1.67 (octane), $1.75((Z)$-4-octene), 1.78 ((E)-4-octene), 1.86 ((Z)-3-octene), 1.94 ((E)-3-octene), 2.29 (4-octyne), Shimadzu GC2014, column Ultra2, crosslinked 5\% PhMe silicone, $25 \mathrm{~m} \times 0.2 \mathrm{~mm} \times 11 \mathrm{~mm}$ ].

\section{Supporting Information}

The supporting information contains further analysis of $\mathrm{Ni} / \mathrm{Ga}$ nanoparticles in the ionic liquids $[\mathrm{BMIm}]\left[\mathrm{BF}_{4}\right]$, [EMIm] $\left[\mathrm{B}(\mathrm{CN})_{4}\right]$, and [EMIm] $\left[\mathrm{BF}(\mathrm{CN})_{3}\right]$, and in propylene carbonate after different dispersion times prior to the decomposition and different time periods of microwave-induced decomposition. Furthermore, additional particle size distributions, XP spectra and catalytic results, as well as particle preparation descriptions are given.

\section{Supporting Information File 1}

Additional experimental details.

[https://www.beilstein-journals.org/bjnano/content/ supplementary/2190-4286-10-171-S1.pdf]

\section{Acknowledgements}

Authors are thankful to the Deutsche Forschungsgemeinschaft (DFG) for financial support in the priority project SPP 1708 through grant Ja466/31-1, Ja466/31-2, Fi502/32-1, FI1628/4-2, PO780/14-1 and the Ernst Ruska-Centre core facilities program through grant MA 1280/40-1. The authors also gratefully acknowledge technical assistance by Max-Planck-Institut für Eisenforschung GmbH, Düsseldorf for TEM measurements.

\section{ORCID ${ }^{\circledR}$ iDs}

Ilka Simon - https://orcid.org/0000-0002-1143-4205 Maik Finze - https://orcid.org/0000-0002-6098-7148 Roland A. Fischer - https://orcid.org/0000-0002-7532-5286 Christoph Janiak - https://orcid.org/0000-0002-6288-9605

\section{References}

1. Wu, S.-H.; Chen, D.-H. J. Colloid Interface Sci. 2003, 259, 282-286. doi:10.1016/s0021-9797(02)00135-2 
2. Luo, X.; Chen, Y.; Yue, G.-H.; Peng, D.-L.; Luo, X. J. Alloys Compd. 2009, 476, 864-868. doi:10.1016/j.jallcom.2008.09.117

3. Golindano, T. d. C.; Martínez, S. I.; Delgado, O. Z.; Rivas, G. P. NSTI Nanotech 2005, 2, 634-637.

4. Alonso, F.; Riente, P.; Yus, M. Eur. J. Org. Chem. 2009, 6034-6042. doi:10.1002/ejoc.200900951

5. Park, J.; Kang, E.; Son, S. U.; Park, H. M.; Lee, M. K.; Kim, J.; Kim, K. W.; Noh, H.-J.; Park, J.-H.; Bae, C. J.; Park, J.-G.; Hyeon, T. Adv. Mater. (Weinheim, Ger.) 2005, 17, 429-434. doi:10.1002/adma.200400611

6. Reina, A.; Favier, I.; Pradel, C.; Gómez, M. Adv. Synth. Catal. 2018, 360, 3544-3552. doi:10.1002/adsc.201800786

7. Alonso, F.; Riente, P.; Yus, M. Tetrahedron 2009, 65, 10637-10643. doi:10.1016/j.tet.2009.10.057

8. Dhakshinamoorthy, A.; Pitchumani, K. Tetrahedron Lett. 2008, 49, 1818-1823. doi:10.1016/j.tetlet.2008.01.061

9. Jiang, H.-y.; Zhang, S.-s.; Sun, B. Catal. Lett. 2018, 148, 1336-1344 doi:10.1007/s10562-018-2361-0

10. Wang, L.; Li, F.; Chen, Y.; Chen, J. J. Energy Chem. 2019, 29, 40-49. doi:10.1016/j.jechem.2018.02.001

11. Trimm, D. L.; Liu, I. O. Y.; Cant, N. W. Appl. Catal., A 2010, 374, 58-64. doi:10.1016/j.apcata.2009.11.030

12. Wang, H.; Li, X.; Li, M.; Xie, K.; Liao, L. Beilstein J. Nanotechnol. 2015, 6, 1268-1271. doi:10.3762/bjnano.6.130

13. Tzitzios, V.; Basina, G.; Gjoka, M.; Alexandrakis, V.; Georgakilas, V.; Niarchos, D.; Boukos, N.; Petridis, D. Nanotechnology 2006, 17, 3750-3755. doi:10.1088/0957-4484/17/15/023

14. Vorobjova, A. I.; Shimanovich, D. L.; Yanushkevich, K. I.; Prischepa, S. L.; Outkina, E. A. Beilstein J. Nanotechnol. 2016, 7, 1709-1717. doi:10.3762/bjnano.7.163

15. Gong, J.; Wang, L. L.; Liu, Y.; Yang, J. H.; Zong, Z. G. J. Alloys Compd. 2008, 457, 6-9. doi:10.1016/j.jallcom.2007.02.124

16. Fernández, G.; Sort, J.; Pleixats, R. ChemistrySelect 2018, 3 , 8597-8603. doi:10.1002/slct.201801839

17. Schunn, R. A.; Ittel, S. D.; Cushing, M. A.; Baker, R.; Gilbert, R. J.; Madden, D. P. Inorg. Synth. 2007, 94-98. doi:10.1002/9780470132593.ch25

18. Vollmer, C.; Redel, E.; Abu-Shandi, K.; Thomann, R.; Manyar, H.; Hardacre, C.; Janiak, C. Chem. - Eur. J. 2010, 16, 3849-3858. doi:10.1002/chem.200903214

19. Siebels, M.; Mai, L.; Schmolke, L.; Schütte, K.; Barthel, J.; Yue, J.; Thomas, J.; Smarsly, B. M.; Devi, A.; Fischer, R. A.; Janiak, C. Beilstein J. Nanotechnol. 2018, 9, 1881-1894. doi:10.3762/bjnano.9.180

20. Konnerth, H.; Prechtl, M. H. G. New J. Chem. 2017, 41, 9594-9597. doi:10.1039/c7nj02210g

21. Wegner, S.; Rutz, C.; Schütte, K.; Barthel, J.; Bushmelev, A.; Schmidt, A.; Dilchert, K.; Fischer, R. A.; Janiak, C. Chem. - Eur. J. 2017, 23, 6330-6340. doi:10.1002/chem.201605251

22. Migowski, P.; Machado, G.; Texeira, S. R.; Alves, M. C. M.; Morais, J.; Traverse, A.; Dupont, J. Phys. Chem. Chem. Phys. 2007, 9, 4814-4821. doi:10.1039/b703979d

23. Borodziński, A.; Bond, G. C. Catal. Rev.: Sci. Eng. 2008, 50, 379-469. doi:10.1080/01614940802142102

24. Maurer, B. R.; Galobardes, M. Selective hydrogenation of phenylacetylene in the presence of styrene. U.S. Patent 4,822,936, April 18, 1989.

25. Molnár, Á.; Sárkány, A.; Varga, M. J. Mol. Catal. A: Chem. 2001, 173, 185-221. doi:10.1016/s1381-1169(01)00150-9
26. Armbrüster, M.; Kovnir, K.; Behrens, M.; Teschner, D.; Grin, Y.; Schlögl, R. J. Am. Chem. Soc. 2010, 132, 14745-14747. doi:10.1021/ja106568t

27. Armbrüster, M.; Wowsnick, G.; Friedrich, M.; Heggen, M.; Cardoso-Gil, R. J. Am. Chem. Soc. 2011, 133, 9112-9118. doi:10.1021/ja202869d

28. Krajčı, M.; Hafner, J. J. Catal. 2012, 295, 70-80. doi:10.1016/j.jcat.2012.07.025

29. Desai, S. P.; Ye, J.; Zheng, J.; Ferrandon, M. S.; Webber, T. E.; Platero-Prats, A. E.; Duan, J.; Garcia-Holley, P.; Camaioni, D. M.; Chapman, K. W.; Delferro, M.; Farha, O. K.; Fulton, J. L.; Gagliardi, L.; Lercher, J. A.; Penn, R. L.; Stein, A.; Lu, C. C. J. Am. Chem. Soc. 2018, 140, 15309-15318. doi:10.1021/jacs.8b08550

30. Schütte, K.; Doddi, A.; Kroll, C.; Meyer, H.; Wiktor, C.; Gemel, C.; van Tendeloo, G.; Fischer, R. A.; Janiak, C. Nanoscale 2014, 6, 5532-5544. doi:10.1039/c4nr00111g

31. Li, C.; Chen, Y.; Zhang, S.; Zhou, J.; Wang, F.; He, S.; Wei, M.; Evans, D. G.; Duan, X. ChemCatChem 2014, 6, 824-831. doi:10.1002/cctc.201300813

32. Hu, M.; Yang, W.; Liu, S.; Zhu, W.; Li, Y.; Hu, B.; Chen, Z.; Shen, R.; Cheong, W.-C.; Wang, Y.; Zhou, K.; Peng, Q.; Chen, C.; Li, Y. Chem. Sci. 2019, 10, 614-619. doi:10.1039/c8sc03178a

33. Feschotte, P.; Eggimann, P. J. Less-Common Met. 1979, 63, 15-30. doi:10.1016/0022-5088(79)90205-4

34. Micke, K.; Markovski, S. L.; Ipser, H.; van Loo, F. J. J. Ber. Bunsen-Ges. 1998, 102, 1240-1244. doi:10.1002/bbpc.19981020930

35. Okamoto, H. J. Phase Equilib. Diffus. 2010, 31, 575-576. doi:10.1007/s11669-010-9785-6

36. Yuan, W. X.; Qiao, Z. Y.; Ipser, H.; Eriksson, G. J. Phase Equilib. Diffus. 2004, 25, 68-74. doi:10.1007/s11669-004-0172-z

37. Studt, F.; Sharafutdinov, I.; Abild-Pedersen, F.; Elkjær, C. F.; Hummelshøj, J. S.; Dahl, S.; Chorkendorff, I.; Nørskov, J. K. Nat. Chem. 2014, 6, 320-324. doi:10.1038/nchem.1873

38. Sharafutdinov, I.; Elkjær, C. F.; Pereira de Carvalho, H. W.; Gardini, D.; Chiarello, G. L.; Damsgaard, C. D.; Wagner, J. B.; Grunwaldt, J.-D.; Dahl, S.; Chorkendorff, I. J. Catal. 2014, 320, 77-88. doi:10.1016/j.jcat.2014.09.025

39. Torelli, D. A.; Francis, S. A.; Crompton, J. C.; Javier, A.; Thompson, J. R.; Brunschwig, B. S.; Soriaga, M. P.; Lewis, N. S. ACS Catal. 2016, 6, 2100-2104. doi:10.1021/acscatal.5b02888

40. Chiang, C. L.; Lin, K. S.; Lin, Y. G. Top. Catal. 2017, 60, 685-696. doi:10.1007/s11244-017-0771-7

41. Tang, Q.; Shen, Z.; Huang, L.; He, T.; Adidharma, H.; Russell, A. G.; Fan, M. Phys. Chem. Chem. Phys. 2017, 19, 18539-18555. doi:10.1039/c7cp03231e

42. Liu, Y.; Liu, X.; Feng, Q.; He, D.; Zhang, L.; Lian, C.; Shen, R.; Zhao, G.; Ji, Y.; Wang, D.; Zhou, G.; Li, Y. Adv. Mater. (Weinheim, Ger.) 2016, 28, 4747-4754. doi:10.1002/adma.201600603

43. Cokoja, M.; Parala, H.; Schröter, M.-K.; Birkner, A.; van den Berg, M. W. E.; Grünert, W.; Fischer, R. A. Chem. Mater. 2006, 18, 1634-1642. doi:10.1021/cm052667w

44. Scholten, J. D.; Ebeling, G.; Dupont, J. Dalton Trans. 2007, 5554-5560. doi:10.1039/b707888a

45. Clement, N. D.; Cavell, K. J.; Jones, C.; Elsevier, C. J. Angew. Chem. 2004, 116, 1297-1299. doi:10.1002/ange.200353409 Angew. Chem., Int. Ed. 2004, 43, 1277-1279. doi:10.1002/anie.200353409 
46. Cadenbach, T.; Gemel, C.; Schmid, R.; Halbherr, M.; Yusenko, K.; Cokoja, M.; Fischer, R. A. Angew. Chem. 2009, 121, 3930-3934. doi:10.1002/ange.200805605

Angew. Chem., Int. Ed. 2009, 48, 3872-3876.

doi:10.1002/anie.200805605

47. Gutel, T.; Garcia-Antõn, J.; Pelzer, K.; Philippot, K.; Santini, C. C.; Chauvin, Y.; Chaudret, B.; Basset, J.-M. J. Mater. Chem. 2007, 17, 3290-3292. doi:10.1039/b706139k

48. Bilecka, I.; Niederberger, M. Nanoscale 2010, 2, 1358-1374. doi:10.1039/b9nr00377k

49. Kölle, U.; Khouzami, F.; Lueken, H. Chem. Ber. 1982, 115, 1178-1196. doi:10.1002/cber.19821150334

50. Moulder, J. F.; Stickle, W. F.; Sobol, P.; Bomben, K. D.; Chastain, J. Handbook of X-ray Photoelectron Spectroscopy; Perkin-Elmer Corporation: New York, NY, U.S.A., 1992.

51. Santner, S.; Heine, J.; Dehnen, S. Angew. Chem. 2016, 128, 886-904. doi:10.1002/ange.201507736

Angew. Chem. Int. Ed. 2016, 55, 876-893. doi:10.1002/anie.201507736

52. Thiele, G.; Santner, S.; Dehnen, S. Z. Kristallogr. - Cryst. Mater. 2017, 232, 8806. doi:10.1515/zkri-2016-1976

53. Groh, M. F.; Isaeva, A.; Ruck, M. Chem. - Eur. J. 2012, 18, 10886-10891. doi:10.1002/chem.201201038

54. Müller, U.; Isaeva, A.; Richter, J.; Knies, M.; Ruck, M. Eur. J. Inorg. Chem. 2016, 2016, 3580-3584. doi:10.1002/ejic.201600637

55. Knies, M.; Kaiser, M.; Isaeva, A.; Müller, U.; Doert, T.; Ruck, M. Chem. - Eur. J. 2018, 24, 127-132. doi:10.1002/chem.201703916

56. Jutzi, P.; Neumann, B.; Reumann, G.; Stammler, H.-G. Organometallics 1998, 17, 1305-1314. doi:10.1021/om970913a

57. Jutzi, P.; Neumann, B.; Reumann, G.; Schebaum, L. O.; Stammler, H.-G. Organometallics 1999, 18, 2550-2552. doi:10.1021/om990045c

58. Buchin, B.; Steinke, T.; Gemel, C.; Cadenbach, T.; Fischer, R. A. Z. Anorg. Allg. Chem. 2005, 631, 2756-2762. doi:10.1002/zaac.200500129

59. Gemel, C.; Steinke, T.; Cokoja, M.; Kempter, A.; Fischer, R. Eur. J. Inorg. Chem. 2004, 4161-4176. doi:10.1002/ejic.200400569

60. Steinke, T.; Gemel, C.; Cokoja, M.; Winter, M.; Fischer, R. A. Angew. Chem. 2004, 116, 2349-2352. doi:10.1002/ange.200353114 Angew. Chem., Int. Ed. 2004, 43, 2299-2302. doi:10.1002/anie.200353114

61. Fürstner, A. J. Am. Chem. Soc. 2019, 141, 11-24. doi:10.1021/jacs.8b09782

62. Karunananda, M. K.; Mankad, N. P. J. Am. Chem. Soc. 2015, 137, 14598-14601. doi:10.1021/jacs.5b10357

63. Zhou, Y.-P.; Mo, Z.; Luecke, M.-P.; Driess, M. Chem. - Eur. J. 2018, 24, 4780-4784. doi:10.1002/chem.201705745

64. Becica, J.; Glaze, O. D.; Wozniak, D. I.; Dobereiner, G. E. Organometallics 2018, 37, 482-490. doi:10.1021/acs.organomet.7b00914

65. Hauwert, P.; Maestri, G.; Sprengers, J. W.; Catellani, M.; Elsevier, C. J. Angew. Chem. 2008, 120, 3267-3270. doi:10.1002/ange.200705638 Angew. Chem., Int. Ed. 2008, 47, 3223-3226. doi:10.1002/anie.200705638

66. Kusy, R.; Grela, K. Org. Lett. 2016, 18, 6196-6199. doi:10.1021/acs.orglett.6b03254

67. Kluwer, A. M.; Koblenz, T. S.; Jonischkeit, T.; Woelk, K.; Elsevier, C. J. J. Am. Chem. Soc. 2005, 127, 15470-15480. doi:10.1021/ja052729j
68. Lee, J.-K.; Kim, D.-W.; Cheong, M.-S.; Lee, H.-J.; Cho, B.-W.; Kim, H.-S.; Mukherjee, D. Bull. Korean Chem. Soc. 2010, 31 , 2195-2200. doi:10.5012/bkcs.2010.31.8.2195

69. Savoia, D.; Tagliavini, E.; Trombini, C.; Umani-Ronchi, A. J. Org. Chem. 1981, 46, 5344-5348. doi:10.1021/jo00339a017

70. Schwab, F.; Weidler, N.; Lucas, M.; Claus, P. Chem. Commun. 2014, 50, 10406-10408. doi:10.1039/c4cc04183f

71. Wagh, Y. S.; Asao, N. J. Org. Chem. 2015, 80, 847-851. doi:10.1021/jo502313d

72. Furukawa, S.; Komatsu, T. ACS Catal. 2016, 6, 2121-2125. doi:10.1021/acscatal.5b02953

73. Tokmic, K.; Fout, A. R. J. Am. Chem. Soc. 2016, 138, 13700-13705. doi:10.1021/jacs.6b08128

74. Bonhôte, P.; Dias, A.-P.; Papageorgiou, N.; Kalyanasundaram, K.; Grätzel, M. Inorg. Chem. 1996, 35, 1168-1178. doi:10.1021/ic951325x

75. Burrell, A. K.; Sesto, R. E. D.; Baker, S. N.; McCleskey, T. M.; Baker, G. A. Green Chem. 2007, 9, 449. doi:10.1039/b615950h

76. Ignat'ev, N. V.; Finze, M.; Sprenger, J. A. P.; Kerpen, C.; Bernhardt, E.; Willner, H. J. Fluorine Chem. 2015, 177, 46-54. doi:10.1016/j.jfluchem.2015.03.007

77. Ignat'ev, N. V.; Finze, M. Eur. J. Inorg. Chem. 2019, 3539-3560. doi:10.1002/ejic.201900403

78. Luysberg, M.; Heggen, M.; Tillmann, K. J. Large-Scale Res. Facil. 2016, 2, A77. doi:10.17815/jlsrf-2-138

79. Thust, A.; Barthel, J.; Tillmann, K. J. Large-Scale Res. Facil. 2016, 2 , A41. doi:10.17815/jlsrf-2-66

\section{License and Terms}

This is an Open Access article under the terms of the Creative Commons Attribution License (http://creativecommons.org/licenses/by/4.0). Please note that the reuse, redistribution and reproduction in particular requires that the authors and source are credited.

The license is subject to the Beilstein Journal of Nanotechnology terms and conditions: (https://www.beilstein-journals.org/bjnano)

The definitive version of this article is the electronic one which can be found at: doi:10.3762/bjnano.10.171 